\title{
Reusing oil and gas produced water for irrigation of food crops in
}

\author{
drylands
}

\author{
Alban Echchelh, Tim Hess* and Ruben Sakrabani \\ Cranfield University, Cranfield, Bedfordshire, MK43 0AL, UK \\ *Corresponding author \\ E-mail address: t.hess@cranfield.ac.uk; \\ Telephone: +44 (0)1234 758305
}

\begin{abstract}
Water scarcity severely affects drylands threatening their food security, whereas, the oil and gas industry produces significant and increasing volumes of produced water that could be partly reused for agricultural irrigation in these regions. In this review, we summarise recent research and provide a broad overview of the potential for oil and gas produced water to irrigate food crops in drylands. There is potentially sufficient water to irrigate about 130000 ha/year of cropland in arid and semi-arid areas. The quality of produced water is often a limiting factor for the reuse in irrigation as it can lead to soil salinisation and sodification. Although the inappropriate use of produced water in irrigation could be damaging for the soil, the agricultural sector in dry areas is often prone to challenges in soil salinity. There is a lack of knowledge about the main environmental and economic conditions that could encourage or limit the development of irrigation with oil and gas effluents at the scale of drylands in the world. Cheaper treatment technologies in combination with farm-based salinity management techniques could make the reuse of produced water relevant to irrigate high value-crops in hyper-arid areas. This review paper approaches an aspect of the energy-
\end{abstract}


water-food nexus: the opportunities and challenges behind the reuse of abundant oil and gas effluents for irrigation in hydrocarbon-rich but water-scarce and food-unsecured drylands. Keywords: water recycling, arid areas, salinity, sodicity

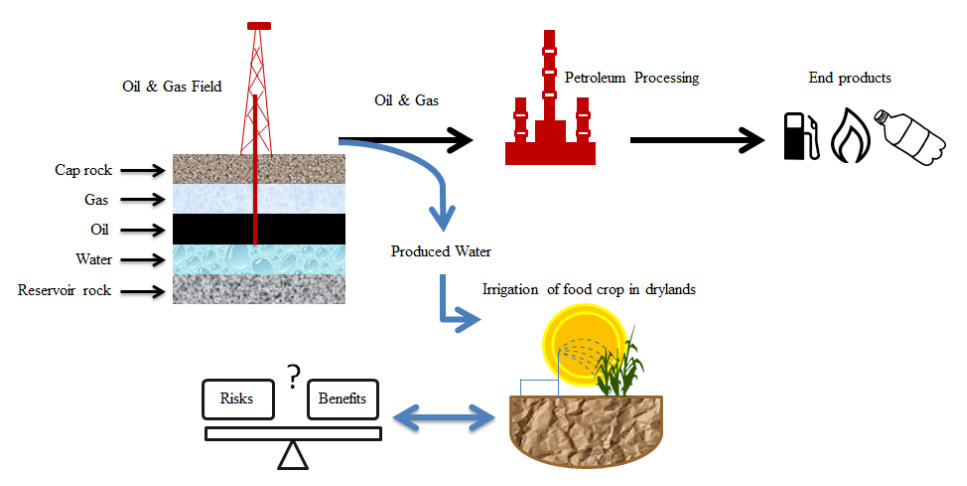

\section{Introduction}

The oil and gas $(\mathrm{O} \& \mathrm{G})$ industry produces large volumes of water during the extraction, processing, and refining of hydrocarbons. The water that is brought to the surface with hydrocarbons during extraction is termed 'produced water' (PW); this often comprises both formation water (which naturally occurs in significant quantities in the reservoir with the hydrocarbons) and water that has been withdrawn from another source, injected into the O\&G reservoir, and returns to the surface with the hydrocarbons (e.g. water injected for enhanced oil recovery and for hydraulic fracturing) (Engle et al., 2014). In terms of volume, PW is by far the largest by-product or waste stream associated with the O\&G industry (Veil, 2011). In certain conditions, PW can be reused for beneficial purposes such as agricultural irrigation, but, the volume of PW currently reused this way represents only a small proportion of the total PW generated. Nonetheless, beneficial reuse of PW is growing (Burnett, 2004; Clark and Veil, 2015) and could provide a substantial volume of irrigation water to crops located near O\&G facilities in drylands (Guerra et al., 2011).

In this paper, drylands are defined by a precipitation to potential evapotranspiration ratio below 0.05 i.e. hyper-arid climate, up to 0.65 i.e. dry sub-humid climate (Barrow, 1992; FAO, 2016; Safriel et al., 2006). Many drylands contain massive hydrocarbon resources (e.g. 
the Persian Gulf, the Western USA, the Gulf of Mexico, the Libyan Desert or the Caspian Sea countries). There are also large coal resources from which gas and synthetic fuels are produced in the USA, China, Australia, and South Africa (Figure 1). The Middle-East North Africa region, which is one of the most populated dry areas (World Bank, 2016), represents about $33 \%$ of the oil production and $23 \%$ of the gas production in the world (EIA, 2016).

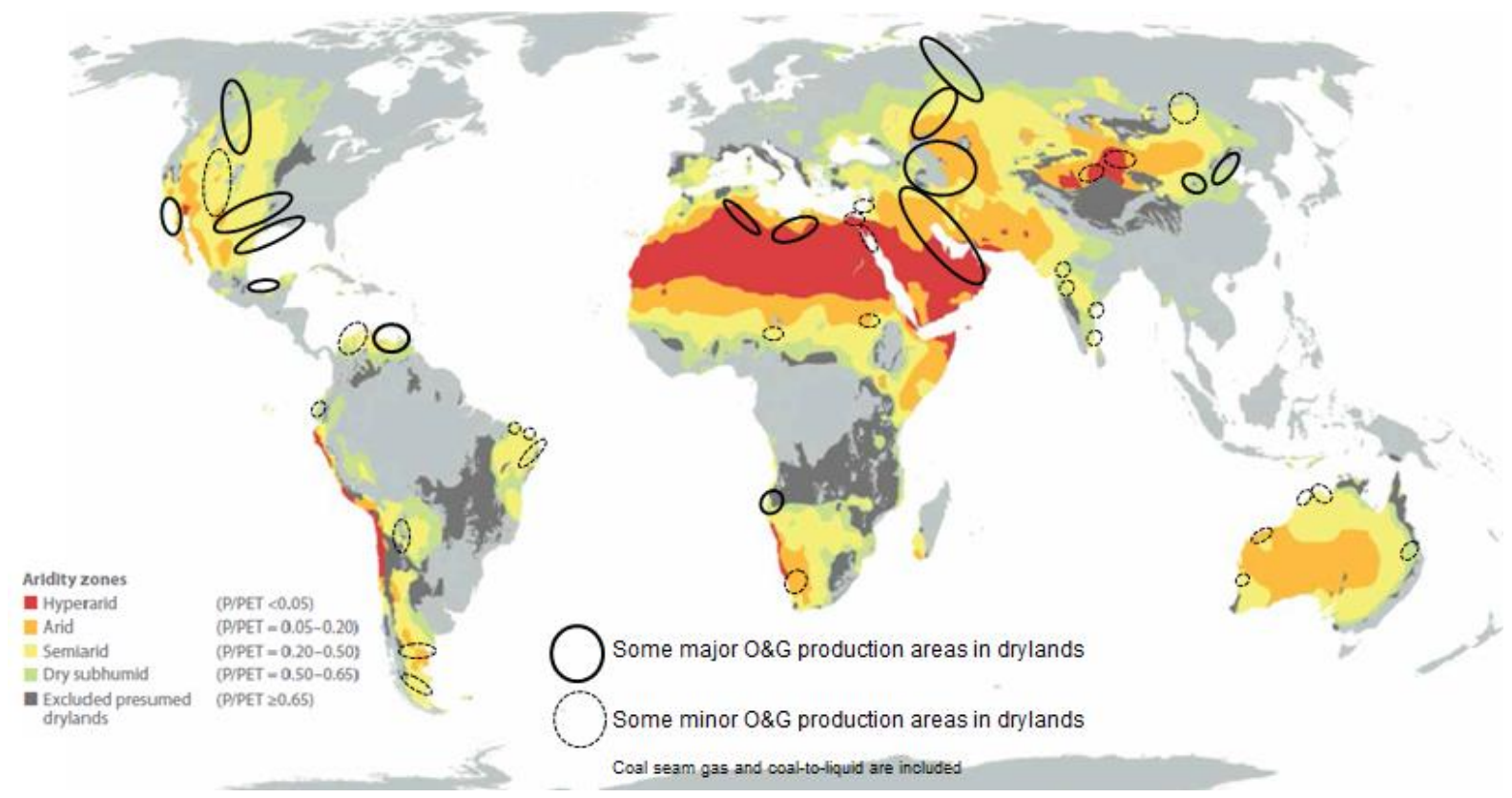

Figure 1. Distribution of drylands and of the main oil and gas production zones located in these areas (adapted from FAO, 2016).

Drylands occur on all continents (Safriel et al., 2006), cover $41 \%$ of the earth's landmass (Millenium Ecosystem Assessment, 2005) and are projected to expand, partly due to climate change (Feng and $\mathrm{Fu}, 2013$ ). These regions are inhabited by 2.1 billion people, many of whom live in developing countries and are directly dependent on the land's natural resources (UN, 2010). Projections estimate that half of the global population will live in regions with high water scarcity by 2030 (UN, 2012). Drylands are an important component of the total agricultural land area as well. About $50 \%$ of the arid and semi-arid area is used for agriculture (Gratzfeld, 2003), drylands grow 44\% of the world's food and support $50 \%$ of the world's livestock (Reid, 2014). In drylands, agriculture represents a major economic activity 
and approximately a third of the population living in these zones depends on agriculture particularly in Africa and in Asia (CGIAR, 2015). Within developed countries, drylands have also significant economic importance. For instance, California represents $13 \%$ of the US GDP making this dry state the major contributor to America's national wealth (US Department of Commerce, 2015). California also produces around $70 \%$ of the fruit and tree nuts, $55 \%$ of the vegetables, $10 \%$ of the cotton and about $30 \%$ of the rice produced in the USA (US Department of Agriculture, 2015). However, agriculture and populations in drylands are under constant threat of water shortage. In fact, drylands are characterised by physical water scarcity because they are naturally prone to lack of water due to their negative water balance (i.e. low precipitation and high evapotranspiration) (Gassert et al., 2014). In addition, fresh water availability can also be reduced by water pollution (NSW Government, 2011) or seawater intrusion (Qadir and Sato, 2015) which can contaminate the already limited fresh water resources. Climate change is projected to increase water scarcity in most drylands, affecting both rain-fed and irrigated agriculture (Pedrick, 2012). As water resources are diminishing, water users (i.e. industry, agriculture, households and the natural environment) are competing more and more for access to water (El-Zanfaly, 2015; Freyman, 2014; Qadir and Sato, 2015).

Therefore, the pressure on water resources from the O\&G industry in drylands is expected to intensify and is likely to exacerbate competition and conflicts between water users, and especially between irrigated farming and unconventional O\&G firms which use fresh water resources (Galbraith, 2013; Hitaj et al., 2014). Reusing O\&G PW for the irrigation of food crops could contribute considerably to improve the sustainability of irrigated agricultural systems in drylands.

This structured review paper aims to provide a critical review of the potential of O\&G PW for the irrigation of food crops in drylands. It starts by providing a review of the volumes and 
qualities of PW from around the world, followed by a discussion of its treatment and management practices. Finally, the potential for reuse of PW in agriculture is discussed and experiences of irrigation with PW are reviewed in order to identify the main risks associated with using PW in practical conditions. The quality of PW is also discussed from an agricultural viewpoint in order to highlight the agronomic and environmental risks associated with reuse and the perspectives for adapting PW to irrigation.

\section{Volume of produced water}

The water-to-oil (WOR) and water-to-gas (WGR) ratios are indicators used to quantify the volume of PW generated compared to the volume of oil or gas produced. Although strictly dimensionless, the O\&G industry generally expresses the ratios as barrels (159 L) of water per barrel of oil or million cubic feet of gas. At the world scale, the average WOR was about 3:1 in the 2000s (Khatib and Verbeek, 2002), and is probably nowadays closer to 4:1, but it can locally range from as low as 0.4 to as high as 36 (Table 1) depending on the field history, the type of hydrocarbon and the technologies employed (Clark and Veil, 2015). Globally, this ratio has been increasing because conventional O\&G fields are ageing so, they produce more and more PW for less hydrocarbons (Healy et al., 2015; Veil et al., 2004). Thus, the highest WOR and WGR are generally related to mature production areas (e.g. California, China, and Oman). However, the WOR and WGR of some fields in the Middle East are still low even if they have been operated for several decades due to specific geological and management conditions of these 'giant fields' which reach their maturation stage much later than smaller fields (Sorkhabi, 2010; Sorrell et al., 2011).

Significant quantities of PW are generated in dry regions (Table 1), although little information is available about volumes of $\mathrm{PW}$ in O\&G producing countries. Indeed, the only significant $\mathrm{O} \& \mathrm{G}$ producer holding public documented information about PW generation and management is the USA (Clark and Veil, 2015, 2009). Contrary to hydrocarbon production 
that has a high economic value, PW volume is often not measured and monitored by O\&G operators (Clark and Veil, 2009). As a consequence, the data in Table 1 are uncertain due to lack of rigorous reporting and monitoring (Clark and Veil, 2015).

The volume of PW and its evolution over time differ between oilfields and gas fields as oil reservoirs usually contain larger volumes of water than gas reservoirs as gas has a higher compressibility and sorption capacity than oil, and also because gas is stored in less porous reservoirs (Guerra et al., 2011). The volume of PW and wells' behaviour are also very heterogeneous between the types of production; conventional O\&G wells typically show a gradual increase of water production while hydrocarbon production is decreasing (Clark and Veil, 2009; Healy et al., 2015). In contrast, in unconventional O\&G production, the volume of PW tends to be correlated with the volume of hydrocarbons extracted (Healy et al., 2015).

Globally, the estimated quantity of PW has increased by more than 78\% between 1990 and 2015 from about 10.6 billion $\mathrm{m}^{3}$ to 18.9 billion $\mathrm{m}^{3}$ compared to $38 \%$ growth of the oil production from 3.7 billion $\mathrm{m}^{3}$ to 5.1 billion $\mathrm{m}^{3}$ respectively. This increasing trend is expected to continue as the projected world PW volume is between 29-54 billion $\mathrm{m}^{3}$ in 2020 (Table 1).

There is an obvious connection between the increase in WOR and the quantity of PW as illustrated by the situation in North America. Conventional O\&G fields in North America are ageing (IEA, 2013); consequently, a significant and continuous increase of PW volume has been observed between 2007 and 2015 from 3.9 to 4.3 billion $\mathrm{m}^{3}$ respectively, it is forecast that 5.6 billion $\mathrm{m}^{3}$ of PW will be generated in 2025 in this part of the world (Shah, 2014). This increase is also partly explained by the rapid development of unconventional hydrocarbons, even if their WOR and WGR are not significantly higher than those of conventional hydrocarbons (Scanlon et al., 2014). Most part of the PW is, and will be, generated in relatively dry states and provinces of North America (Guerra et al., 2011) 
Table 1. Estimates of water-to-oil ratios (WOR $=\mathrm{m}^{3}$ of produced water $/ \mathrm{m}^{3}$ of oil produced), water-to-gas ratios (WGR $=\mathrm{m}^{3}$ of produced water/1000 $\mathrm{m}^{3}$ of gas produced), and total volumes of produced water (PW) by type of production and country or region located in drylands.

\begin{tabular}{|c|c|c|c|c|c|c|}
\hline Country-Region-Field & Type of production & WOR & WGR & $\mathrm{PW}$ volume ( $\mathrm{m}^{3} /$ year$)$ & Year & Reference \\
\hline World-Total 1990 & All & 2.9 & - & 10590541521 & 1990 & $1 ; 2 ; 3$ \\
\hline World-Total 2000 & All & 2.9 & - & 12186376545 & 2000 & $1 ; 2 ; 3 ; 4$ \\
\hline World-Total 2010 & All & 3.6 & - & 16886836070 & 2010 & $1 ; 2 ; 3 ; 5$ \\
\hline World-Total 2015 & All & 3.7 & - & 18859868463 & 2015 & $1 ; 2 ; 3$ \\
\hline $\begin{array}{l}\text { World-Total } 2020 \\
\text { (forecast low estimation) }\end{array}$ & All onshore & 5.6 & - & 29015182250 & 2020 & $1 ; 6$ \\
\hline $\begin{array}{l}\text { World-Total } 2020 \\
\text { (forecast high estimation) }\end{array}$ & All & 10.5 & - & 54020000000 & 2020 & $1 ; 7$ \\
\hline USA & All & 10.0 & 0.6 & 3367453720 & 2012 & $8 ; 9$ \\
\hline USA-Texas & All & - & - & 1182175348 & 2012 & $8 ; 9$ \\
\hline USA-Texas-New Mexico-Permian & All & 9 & - & 953923800 - & 2014 & $10 ; 11$ \\
\hline USA-California & All & 15.5 & 0.1 & 524658090 & 2014 & $9 ; 12$ \\
\hline USA-Wyoming & All & 36.3 & 1.4 & 346284674 & 2012 & 9 \\
\hline USA-New Mexico & All & 7.9 & 0.5 & 123363016 & 2012 & 9 \\
\hline USA-North Dakota & All & 1.2 & 0.1 & 46288675 & 2012 & 9 \\
\hline
\end{tabular}




\begin{tabular}{|c|c|c|c|c|c|c|}
\hline Country-Region-Field & Type of production & WOR & WGR & $\mathrm{PW}$ volume ( $\mathrm{m}^{3} /$ year $)$ & Year & Reference \\
\hline USA-Montana & All & 6.8 & 0.3 & 29068125 & 2012 & 9 \\
\hline USA-Nebraska & All & 23.0 & 3.6 & 9323174 & 2012 & 9 \\
\hline USA-Nevada & All & 15.9 & - & 932461 & 2012 & 9 \\
\hline USA-South Dakota & All & 3.0 & - & 841997 & 2012 & 9 \\
\hline USA-Arizona & All & 1.3 & 0.3 & 12878 & 2012 & 9 \\
\hline Canada & All & 11 & - & - & 2010 & 13 \\
\hline Mexico & All & 3 & - & - & 2010 & 13 \\
\hline China & All & 9 & - & - & 2010 & 13 \\
\hline Australia & All & - & 0.2 & 33000000 & 2010 & $14 ; 15 ; 16$ \\
\hline USA-California-Kern River & Conventional & 15 & - & 52227328 & 2005,2008 & $17 ; 18$ \\
\hline Saudi Arabia & Conventional & $1-3$ & - & - & 2010,2015 & $13 ; 19$ \\
\hline Saudi Arabia-Qatif and Khursaniyah & Conventional & 2.3 & - & - & 2009 & 20 \\
\hline Saudi Arabia-Ghawar & Conventional & 0.4 & - & - & 2003 & 21 \\
\hline Iraq-North Rumaila & Conventional & - & - & $16828806-46424292$ & 2013 & 22 \\
\hline Iraq-Kirkuk & Conventional & 2 & - & - & 2009 & 20 \\
\hline
\end{tabular}




\begin{tabular}{|c|c|c|c|c|c|c|}
\hline Country-Region-Field & Type of production & WOR & WGR & $\mathrm{PW}$ volume $\left(\mathrm{m}^{3} /\right.$ year$)$ & Year & Reference \\
\hline Oman & Conventional & 10.0 & - & 292000000 & 2007 & 23 \\
\hline Oman-South fields & Conventional & 3 & - & - & 2007 & 24 \\
\hline Oman-Nimr & Conventional & 10.0 & - & 98550000 & 2009 & 23 \\
\hline Kuwait & Conventional & 0.4 & - & - & 2016 & 25 \\
\hline Qatar & Conventional & 3.0 & & - & 2014,2016 & $26 ; 27$ \\
\hline USA-Wyoming-Powder River & Coalbed Methane & - & 15.4 & 63531643 & 2000 & 28 \\
\hline USA-New Mexico-Colorado-San Juan & Coalbed Methane & - & 0.2 & 4481395 & 2000 & 28 \\
\hline USA-Colorado-Raton & Coalbed Methane & - & 7.5 & 7085159 & 2000 & 28 \\
\hline USA-Utah-Uinta & Coalbed Methane & - & 2.4 & 4903276 & 2000 & 28 \\
\hline Australia-Queensland-Surat & Coalbed Methane & - & - & 125000000 & 2015 & 14 \\
\hline Australia-New South Wales-Sydney & Coalbed Methane & - & - & 4800 & 2012 & 29 \\
\hline USA-Texas-Eagle Ford & Shale (tight) & 1.4 & 0.6 & 397468250 & 2014 & 30 \\
\hline USA-Colorado & Shale (tight) & 2.5 & - & 56979299 & 2012,2015 & $9 ; 31$ \\
\hline USA-North Dakota-Montana-Bakken & Shale (tight) & 3 & - & 42926571 & 2014,2015 & $32 ; 33$ \\
\hline USA-Utah & Shale (tight) & 3 & - & 26542135 & 2012 & $9 ; 31$ \\
\hline
\end{tabular}




\begin{tabular}{|c|c|c|c|c|c|c|}
\hline Country-Region-Field & Type of production & WOR & WGR & PW volume $\left(\mathrm{m}^{3} /\right.$ year $)$ & Year & Reference \\
\hline China-Liaoning-Liaohe & Heavy oil & - & - & 7300000 & 2011 & 34 \\
\hline Mexico-Maya & Heavy oil & 3 & - & - & 2009 & 20 \\
\hline Canada-Alberta & Oil sands & $0.4-5.0$ & - & - & 2010,2013 & $35 ; 36$ \\
\hline
\end{tabular}

${ }^{1}$ (BP, 2017); ${ }^{2}$ (Dal Ferro and Smith, 2007); ${ }^{3}$ (SPE, 2011); ${ }^{4}$ (Khatib and Verbeek, 2002); ${ }^{5}$ (Fakhru'l-Razi et al., 2009); ${ }^{6}$ (Stanic, 2014$) ;{ }^{7}$ (Transparency Market Research, 2016); ${ }^{8}$ (Burnett, 2004); ${ }^{9}$ (Clark and Veil, 2015); ${ }^{10}$ (Digital H2O, 2015); ${ }^{11}$ (Sharr, 2014); ${ }^{12}$ (Waterfind, 2016); ${ }^{13}$ (Jacobs Consultancy, 2010); ${ }^{14}$ (Commonwealth of Australia, 2014); ${ }^{15}$ (IESC, 2014); ${ }^{16}$ (Blackam, 2017); ${ }^{17}$ (Robles, 2016); ${ }^{18}$ (Waldron, 2005); ${ }^{19}$ (Al-Haddabi et al., 2015); ${ }^{20}$ (Keesom et al., 2009); ${ }^{21}$ (Sorkhabi, 2010); ${ }^{22}$ (Kuraimid, 2013); ${ }^{23}$ (Breuer, 2011); ${ }^{24}$ (Al-Mahrooqi et al., 2007); ${ }^{25}$ (Alanezi, 2016); ${ }^{26}$ (Ahan, 2014); ${ }^{27}$ (Gulf Intelligence, 2016); ${ }^{28}$ (Rice and Nuccio, 2000); ${ }^{29}$ (NSW Government, 2013); ${ }^{30}$ (Scanlon et al., 2014); ${ }^{31}$ (Gordon, 2015); ${ }^{32}$ (Kurz et al., 2016); ${ }^{33}$ (Terrel, 2015); ${ }^{34}$ (Vaz and Di Falco, 2011); ${ }^{35}$ (Williams and Simmons, 2013); ${ }^{36}$ (Miller, 2010) 


\section{Quality of produced water}

PW contains a mixture of organic and inorganic materials (Table 2) including dissolved and dispersed oil, dissolved formation minerals, production chemical compounds, production solids (e.g. formation solids, corrosion and scale products, bacteria, waxes, and asphaltenes), naturally occurring radioactive materials (NORM) and dissolved gases (Deng et al., 2008; Ekins et al., 2007; Fakhru'l-Razi et al., 2009; Hansen and Davies, 1994; McCormack et al., 2001; Neff, 2002; Neff et al., 2011; Stephenson, 1992; Veil et al., 2004; Wang et al., 2001). The detailed chemical composition and physical characteristics of PW partly depend on the type of hydrocarbon associated with PW. For example, PW from gas production usually has lower total dissolved solids (TDS), oil, and grease content than that from oil production. PW quality also differs according to the geology of the storage formation from which they are withdrawn, the operational conditions, the age of the well, and the chemicals used in process facilities (Abousnina et al., 2015; Igunnu and Chen, 2014; Neff et al., 2011; Pichtel, 2016; Veil et al., 2004). In addition, like the volume, the composition of PW can vary over time within the same well (Veil et al., 2004). 
Table 2. Ranges of some physical and chemical parameters of typical oil and gas produced water compared to FAO guidelines for irrigation water and US EPA national discharge standards. COPW: Conventional oil produced water; CGPW: Conventional gas produced water; TOPW: Tight oil produced water SGPW: Shale gas produced water; CBMPW: Coalbed methane produced water; BDL: Below Detection Level.

\begin{tabular}{|c|c|c|c|c|c|c|}
\hline & $\mathrm{COPW}^{1 ; 2 ; 3}$ & $\mathrm{CGPW}^{1 ; 2 ; 4 ; 5}$ & TOPW $^{1}$ & SGPW $^{1 ; 6 ; 7}$ & CBMPW $^{1 ; 5 ; 8 ; 9 ; 10 ; 11}$ & $\begin{array}{c}\text { FAO guidelines }{ }^{12} \text { or US } \\
\text { EPA standards }\end{array}$ \\
\hline $\mathrm{EC}(\mu \mathrm{S} / \mathrm{cm})$ & $621-359000$ & $621-359000$ & $78400-373400$ & $0.03-763000$ & $9-40380$ & $\begin{array}{l}0<\mathrm{SAR}<3 \text { if } \mathrm{EC}> \\
0.7\end{array}$ \\
\hline \multirow[t]{3}{*}{ SAR } & $1-3759$ & - & $430-1014$ & $2-1497$ & $4-1567$ & $\begin{array}{l}3<\mathrm{SAR}<6 \text { if } \mathrm{EC}> \\
1.26\end{array}$ \\
\hline & & & & & & $\begin{array}{l}12<\mathrm{SAR}<20 \text { if } \mathrm{EC}> \\
2.9\end{array}$ \\
\hline & & & & & & $\begin{array}{l}20<\mathrm{SAR}<40 \text { if } \mathrm{EC}> \\
5\end{array}$ \\
\hline $\mathrm{Cl}^{-}(\mathrm{mg} / \mathrm{L})$ & 80-292000 & $3000-200000$ & $1-310561$ & $1-196000$ & $0.8-110000$ & $0-1050$ \\
\hline $\mathrm{HCO}_{3}{ }^{-}(\mathrm{mg} / \mathrm{L})$ & $77-3990$ & $100-6000$ & $0.6-18916$ & $0.01-13880$ & $19-43310$ & $0-8.5$ \\
\hline
\end{tabular}




\begin{tabular}{|c|c|c|c|c|c|c|}
\hline & $\mathrm{COPW}^{1 ; 2 ; 3}$ & $\mathrm{CGPW}^{1 ; 2 ; 4 ; 5}$ & TOPW $^{1}$ & $\mathrm{SGPW}^{1 ; 6 ; 7}$ & $\mathrm{CBMPW}^{1 ; 5 ; 8 ; 9 ; 10 ; 11}$ & $\begin{array}{c}\text { FAO guidelines }{ }^{12} \text { or US } \\
\text { EPA standards }{ }^{13}\end{array}$ \\
\hline $\mathrm{SO}_{4}{ }^{2-}(\mathrm{mg} / \mathrm{L})$ & $<2-1650$ & BDL-5000 & $0.7-11300$ & $0.1-3580$ & BDL-1800 & $0-960$ \\
\hline $\mathrm{NO}_{3}{ }^{-}(\mathrm{mg} / \mathrm{L})$ & - & - & - & - & 0.01 & $0-30$ \\
\hline $\mathrm{PO}_{4}{ }^{3-}(\mathrm{mg} / \mathrm{L})$ & - & - & - & $0.03-51$ & BDL-9199 & $0-2$ \\
\hline $\mathrm{Na}(\mathrm{mg} / \mathrm{L})$ & 122000 & 2000-100 000 & $49.9-124400$ & $3.6-434403$ & $2.6-51700$ & 0-920 \\
\hline $\mathrm{K}(\mathrm{mg} / \mathrm{L})$ & $24-4300$ & BDL-750 & $7-8526$ & $2-17043$ & $0.1-20100$ & $0-2$ \\
\hline $\mathrm{Ca}(\mathrm{mg} / \mathrm{L})$ & $13-42800$ & 24 & $10-132687$ & $1.95-162324$ & $0.42-13900$ & 400 \\
\hline $\mathrm{B}(\mathrm{mg} / \mathrm{L})$ & $5-95$ & BDL-56 & $63-564$ & $0.01-155$ & $0.05-10$ & $0-3$ \\
\hline $\mathrm{Cd}(\mathrm{mg} / \mathrm{L})$ & $<0.005-0.2$ & BDL-0.015 & $0.024-0.067$ & $0.001-0.1$ & $0.0001-1.4$ & $0-0.01$ \\
\hline $\mathrm{Cr}(\mathrm{mg} / \mathrm{L})$ & $0.02-1.1$ & BDL-0.03 & $0.045-318$ & $0.001-14$ & $0.001-3.7$ & $0-0.1$ \\
\hline $\mathrm{Cu}(\mathrm{mg} / \mathrm{L})$ & $<0.002-1.5$ & BDL-5 & $0.009-1.5$ & $0.01-2.6$ & $0.002-4.6$ & $0-0.2$ \\
\hline $\mathrm{Fe}(\mathrm{mg} / \mathrm{L})$ & $<0.1-100$ & BDL-1100 & $0.05-800$ & $0.18-1247$ & $0.005-4180$ & $0-5$ \\
\hline
\end{tabular}




\begin{tabular}{|c|c|c|c|c|c|c|}
\hline & $\mathrm{COPW}^{1 ; 2 ; 3}$ & $\mathrm{CGPW}^{1 ; 2 ; 4 ; 5}$ & TOPW $^{1}$ & SGPW $^{1 ; 6 ; 7}$ & CBMPW $^{1 ; 5 ; 8 ; 9 ; 10 ; 11}$ & $\begin{array}{c}\text { FAO guidelines }{ }^{12} \text { or US } \\
\text { EPA standards }{ }^{13}\end{array}$ \\
\hline Li (mg/L) & $3-50$ & $19-235$ & $7.1-90.1$ & $0.009-426$ & BDL-36 & $0-2.5$ \\
\hline $\mathrm{Mn}(\mathrm{mg} / \mathrm{L})$ & $<0.004-175$ & $0.04-1$ & $1.54-29.4$ & $0.01-24$ & $0.0018-6$ & $0-0.2$ \\
\hline Ni (mg/L) & $<0.001-1.7$ & BDL-9.2 & $0.183-0.397$ & BDL-36.5 & $0.0001-19.2$ & $0-0.2$ \\
\hline $\mathrm{Pb}(\mathrm{mg} / \mathrm{L})$ & $0.002-8.8$ & $<0.02-10.2$ & $0.006-1.210$ & $0.001-0.7$ & $0.001-0.2$ & $0-5$ \\
\hline $\mathrm{Zn}(\mathrm{mg} / \mathrm{L})$ & $<0.01-35$ & BDL-5 & $0.134-29$ & BDL-182 & $0.001-51$ & $0-2$ \\
\hline $\begin{array}{l}\text { Oil and grease } \\
(\mathrm{mg} / \mathrm{L})\end{array}$ & 0.565 & $0.29-38.8$ & - & - & 2.2 & $35^{13}$ \\
\hline
\end{tabular}

${ }^{1}$ (USGS, 2016); ${ }^{2}$ (Engle et al., 2014); ${ }^{3}$ (Pichtel, 2016); ${ }^{4}$ (Fakhru'l-Razi et al., 2009); ${ }^{5}$ (Xu et al., 2008); ${ }^{6}$ (Alleman, 2011); ${ }^{7}$ (Maguire-Boyle and Barron, 2014); ${ }^{8}$ (Abousnina et al., 2015); ${ }^{9}$ (Commonwealth of Australia, 2014); ${ }^{10}$ (Jackson and Myers, 2002); ${ }^{11}$ (Khan and Kordek, 2013);

${ }^{12}$ (Ayers and Westcot, 1985); ${ }^{13}$ (US EPA, 1995) 
As we see in Table 2 the ranges of chemical concentration in the different kinds of O\&G PW vary widely. From an agronomic point of view, PW typically has high TDS, high electrical conductivity (EC), high sodium adsorption ratio (SAR), acidic to alkaline pH. PW also contains moderate to high amounts of various heavy metals such as $\mathrm{B}, \mathrm{Cd}, \mathrm{Cr}, \mathrm{Cu}, \mathrm{Pb}$, Ni, and Zn (ALL Consulting, 2003; Clark and Veil, 2009; Hansen and Davies, 1994; Pichtel, 2016; Van Voast, 2003).

\section{Management of produced water}

Due to its complex composition, PW needs to be managed in order to avoid environmental damage. Treatment and reuse or disposal options depend on the constituents of PW, the location of the oil or gas field (e.g. onshore or offshore) and the environmental regulation of the territory where the hydrocarbon is produced. For example, oil and grease receive the most attention for both onshore and offshore PW, whereas salt content is of concern for onshore PW.

\subsection{Treatment}

The treatment options include de-oiling, desalination, degassing, suspended solids removal, organic compounds removal, heavy metal and radionuclides removal, and disinfection (SPE, 2011). These treatment goals are essentially the same for beneficial reuse or disposal, although the level of contaminant removal required for reuse in irrigation can be significantly higher, depending on the original quality of the PW and the type of reuse. Achieving the various treatment goals requires the use of multiple treatment technologies, including physical, chemical, and biological treatment processes (Fakhru'l-Razi et al., 2009). The treatment cost strongly depends on the quality of PW (which can vary widely among production fields and change over time within a given field) and the regulatory environment. Therefore, technology solutions for treatment and reuse of PW would need to be adapted according to the properties of the PW and the amount of water to be treated (SPE, 2011). 


\subsection{Management options}

The final destination of the PW (i.e. disposal or reuse) is highly dependent on its quality and also the location of the $\mathrm{O} \& \mathrm{G}$ field. Table 3 shows that most PW is reinjected into underground formations. When used to improve oil recovery, PW ceases to be a waste and becomes a useful resource. Surface discharge is the second most common practice while reinjection in disposal wells is the third. In these cases, PW is not used in a beneficial way and is considered as a waste. PW reuse (other than reuse for enhanced oil recovery) remains a minor practice although it is expected to develop in the future due to the reuse of higher proportion of PW that is currently discharged to the surface and reinjected for disposal (Global Water Intelligence, 2014; Veil et al., 2004). Despite the projected increase in PW volume, the shares of non-beneficial uses of PW (disposal and discharge) will decrease compared to beneficial uses (enhanced oil recovery and other beneficial reuses).

Table 3. Global oil and gas produced water management practices in 2012 compared to 2020 forecast after Global Water Intelligence (2014)

\begin{tabular}{lcc}
\hline Management option & $\begin{array}{c}\text { Share of PW volume in } \\
2012(\%)\end{array}$ & $\begin{array}{c}\text { Expected share of PW volume in } \\
2020(\%)\end{array}$ \\
\hline $\begin{array}{l}\text { Reinjection for enhanced oil } \\
\text { recovery }\end{array}$ & 52 & 56 \\
Reinjection for disposal & 19 & 15 \\
Surface discharge & 21 & 17 \\
Other non-beneficial practices & 5 & 5 \\
Beneficial reuse & 3 & 7 \\
\hline
\end{tabular}

Management practices vary between regions. In the USA for instance, in 2007, about 95\% of the PW was managed through underground injection practices (i.e. $55 \%$ for enhanced oil recovery and $39 \%$ for disposal), the remaining $5 \%$ of water was discharged to surface water, 
stored in surface impoundments, reused for irrigation, or reused for hydraulic fracturing (Clark and Veil, 2009; Hladik et al., 2014).

Management practices also differ between onshore and offshore fields. Most onshore O\&G PW is reinjected whilst offshore O\&G PW tends to be discharged, due to the isolation of offshore O\&G facilities from potential reuse options. Indeed, globally, in 2014, an estimated 844 million $\mathrm{m}^{3}$ of PW were discharged offshore (IOGP, 2014) representing $84 \%$ of the total volume of offshore PW in 2013 (Water Online, 2014). The variability of offshore PW management practices is less compared to onshore PW. For example, the estimated total volume of PW generated in the USA's federal waters in 2007 was about 93 million $\mathrm{m}^{3}, 91 \%$ was treated and discharged to the ocean and only $9 \%$ of this PW was reinjected underground for enhanced recovery or disposal (Clark and Veil, 2009). In Europe's offshore waters (mainly the North Sea), about 419 million $\mathrm{m}^{3}$ of PW were discharged in 2014 whereas about 100 million $\mathrm{m}^{3}$ were reinjected in 2012 (Garland, 2005; IOGP, 2014).

PW that is discharged, disposed of, and not used beneficially represented $45 \%$ of global PW volume in 2012 (Table 3). Thus, considering the 18.86 billion $\mathrm{m}^{3}$ of PW generated in 2015 (Table 1), about 8.5 billion $\mathrm{m}^{3}$ of PW is potentially available for agricultural irrigation.

\section{Potential of produced water for reuse in irrigation}

\subsection{Experience of irrigation with oil and gas produced water}

Among the possible beneficial reuses of PW, agricultural irrigation (especially of food crops) could be particularly relevant in drylands. Table 4 presents theoretical research, laboratory and field experiments, as well as examples of large-scale use of PW for irrigation in different parts of the world. Table 4 helps to identify the challenges faced when PW is used for irrigation in dry zones. It also supports the idea that PW in conjunction with adapted management has an important potential to increase water resources in drylands. 
Table 4. Cases of irrigation of food crops and non-food crops with oil and gas wastewater and main outcomes (CBM: Coalbed Methane, COD: Chemical Oxygen Demand, EC: Electrical Conductivity, OM: Organic Matter, SAR: Sodium Adsorption Ratio, TDS: Total Dissolved Solids)

\begin{tabular}{|c|c|c|c|c|c|c|c|c|}
\hline $\begin{array}{l}\text { Country } \\
\text { (Region) }\end{array}$ & $\begin{array}{l}\text { Type of O\&G } \\
\text { field associated } \\
\text { to the PW used }\end{array}$ & $\begin{array}{l}\text { Water } \\
\text { treatment }\end{array}$ & $\begin{array}{l}\text { Quality of the } \\
\text { water applied }\end{array}$ & Soil type & $\begin{array}{l}\text { Soil } \\
\text { amendments } \\
\text { applied }\end{array}$ & Crop irrigated & Main observations & Ref. \\
\hline $\begin{array}{l}\text { USA } \\
\text { (Wyoming) }\end{array}$ & $\begin{array}{l}\text { Conventional } \\
\text { oilfield PW }\end{array}$ & Untreated & $\begin{array}{l}\mathrm{TDS}=3220 \\
\mathrm{mg} / \mathrm{L} \\
\mathrm{Na}=642 \\
\mathrm{mg} / \mathrm{L} \\
\mathrm{SAR}=9.79\end{array}$ & $\begin{array}{l}\text { Soilless } \\
\text { cultivation } \\
\text { (hydroponic) }\end{array}$ & $\begin{array}{l}\text { Fertilisers: } \\
\mathrm{KNO}_{3} ; \\
\mathrm{Ca}\left(\mathrm{NO}_{3}\right)_{2} \\
\mathrm{MgSO}_{4} \\
\text { pH regulator: } \\
\mathrm{H}_{2} \mathrm{SO}_{4}\end{array}$ & Tomato & $\begin{array}{l}\text { Yield reduction ( } 3 \\
\text { times lower compared } \\
\text { to control). } \\
\text { More } \mathrm{Na} \text { and metals } \\
\text { absorption by plants } \\
\text { than in control. }\end{array}$ & 1 \\
\hline $\begin{array}{l}\text { USA } \\
\text { (Wyoming) }\end{array}$ & CBM PW & Untreated & $\begin{array}{l}\mathrm{TDS}=1390 \\
\mathrm{mg} / \mathrm{L} \\
\mathrm{Na}=555 \\
\mathrm{mg} / \mathrm{L} \\
\mathrm{SAR}=5.73\end{array}$ & Clay loam & $\begin{array}{l}\text { Fertilisers: NPK } \\
(18-6-12)\end{array}$ & $\begin{array}{l}\text { Corn, } \\
\text { switchgrass, } \\
\text { spearmint, } \\
\text { Japanese corn } \\
\text { mint, } \\
\text { lemongrass, } \\
\text { common } \\
\text { wormwood }\end{array}$ & $\begin{array}{l}\text { Increase } \mathrm{Na} \text { and } \\
\text { decrease } \mathrm{Ca}^{2+} \text { and } \\
\mathrm{Mg}^{2+} \text { concentrations } \\
\text { in soil. } \\
\text { Elevated leaf } \mathrm{Na} \\
\text { content in plant. } \\
\text { Untreated CBM PW } \\
\text { can be used for short } \\
\text { periods ( } 2 \text { years). }\end{array}$ & 2 \\
\hline $\begin{array}{l}\text { USA } \\
\text { (Alabama) }\end{array}$ & CBM PW & $\begin{array}{l}\text { Blending with } \\
\text { freshwater }\end{array}$ & $\begin{array}{l}\mathrm{EC}=10600 \\
\mu \mathrm{S} / \mathrm{cm} \\
\mathrm{TDS}=6780 \\
\mathrm{mg} / \mathrm{L} \\
\mathrm{SAR}=73\end{array}$ & $\begin{array}{l}\text { Sand }=28.9 \% \\
\text { Silt }=50.5 \% \\
\text { Clay }=20.6 \%\end{array}$ & $\begin{array}{l}\text { Fertilisers: } \mathrm{N} \\
(30 \mathrm{mg} / \mathrm{kg} \text { of } \\
\text { soil })\end{array}$ & $\begin{array}{l}\text { Sorghum, } \\
\text { Sudangrass }\end{array}$ & $\begin{array}{l}\text { CBM PW (TDS = } \\
2000 \mathrm{mg} / \mathrm{L} \text { ) can be } \\
\text { applied to highly } \\
\text { weathered soils. } \\
\text { Plant growth of } \\
\text { summer annual } \\
\text { grasses will be }\end{array}$ & 3 \\
\hline
\end{tabular}




\begin{tabular}{|c|c|c|c|c|c|c|c|}
\hline $\begin{array}{l}\text { Country } \\
\text { (Region) }\end{array}$ & $\begin{array}{l}\text { Type of O\&G } \\
\text { field associated } \\
\text { to the PW used }\end{array}$ & $\begin{array}{l}\text { Water } \\
\text { treatment }\end{array}$ & $\begin{array}{l}\text { Quality of the } \\
\text { water applied }\end{array}$ & Soil type & $\begin{array}{l}\text { Soil } \\
\text { amendments } \\
\text { applied }\end{array}$ & Crop irrigated & Main observations \\
\hline
\end{tabular}

optimised if an

irrigation system is used to apply PW at a rate to maintain soil moisture at or near field capacity.

\begin{tabular}{|c|c|c|c|c|}
\hline $\begin{array}{l}\text { USA } \\
\text { (California) }\end{array}$ & $\begin{array}{l}\text { Conventional } \\
\text { oilfield PW }\end{array}$ & $\begin{array}{l}\text { Mechanical } \\
\text { separation, } \\
\text { sedimentation, } \\
\text { air flotation } \\
\text { and filtration }\end{array}$ & $\begin{array}{l}\mathrm{TDS}=500 \\
\mathrm{mg} / \mathrm{L} \\
\mathrm{Na}=130 \\
\mathrm{mg} / \mathrm{L}\end{array}$ & $\begin{array}{l}\text { Saline-alkaline } \\
\text { soils with } \\
\text { diverse texture }\end{array}$ \\
\hline Oman & $\begin{array}{l}\text { Conventional } \\
\text { oilfield PW }\end{array}$ & $\begin{array}{l}\text { Reed, solar } \\
\text { distillation }\end{array}$ & $\begin{array}{l}\mathrm{TDS} \leq 50 \\
\mathrm{mg} / \mathrm{L}\end{array}$ & - \\
\hline
\end{tabular}

Grape, almond, Trace of organic citrus, pistachio, chemical below apple, peach, drinking standards. plum, melon, Water considered safe potato, for irrigation.

vegetables

Eucalyptus, Kuwaiti tree,

The PW is desalinised using a commercial paspalum, cotton solar powered system called 'Solar Dew' which is especially adapted to arid environments. The desalination cost $0.5-$ $2 \mathrm{USD} / \mathrm{m}^{3}$ is thus much lower compared to an electric or fuelpowered desalination unit. After treatment by reeds, the $\mathrm{PW}$ is saline (TDS $=6980$ $\mathrm{mg} / \mathrm{L}$ ). The solar desalination system 


\begin{tabular}{|c|c|c|c|c|c|c|c|}
\hline $\begin{array}{l}\text { Country } \\
\text { (Region) }\end{array}$ & $\begin{array}{l}\text { Type of O\&G } \\
\text { field associated } \\
\text { to the PW used }\end{array}$ & $\begin{array}{l}\text { Water } \\
\text { treatment }\end{array}$ & $\begin{array}{l}\text { Quality of the } \\
\text { water applied }\end{array}$ & Soil type & $\begin{array}{l}\text { Soil } \\
\text { amendments } \\
\text { applied }\end{array}$ & Crop irrigated & Main observations \\
\hline
\end{tabular}

produced an effluent reaching WHO potable standards (TDS $\leq 50 \mathrm{mg} / \mathrm{L}$ ).

\begin{tabular}{|c|c|c|c|c|c|}
\hline Oman & $\begin{array}{l}\text { Conventional } \\
\text { oilfield PW }\end{array}$ & $\begin{array}{l}\text { Air flotation, } \\
\text { anthracite } \\
\text { filtration, } \\
\text { activated } \\
\text { carbon }\end{array}$ & $\begin{array}{l}\mathrm{EC}=8000 \\
\mu \mathrm{S} / \mathrm{cm} \\
\mathrm{TDS}=3000 \\
6000 \mathrm{mg} / \mathrm{L}\end{array}$ & $\begin{array}{l}\text { Mixture of } \\
\text { gravel (top } \\
\text { layer } 8 \mathrm{~cm}), \\
\text { sand }(40 \mathrm{~cm}) \\
\text { and OM }\end{array}$ & $\begin{array}{l}\text { None except } \\
\text { than OM } \\
\text { initially added } \\
\text { to create an } \\
\text { experimental } \\
\text { soil }\end{array}$ \\
\hline
\end{tabular}

Alfalfa, barley, Increased soil salinity Rhodes grass and sodicity.

Decrease of soil salinity when lowsalinity water is frequently used to leach salts.

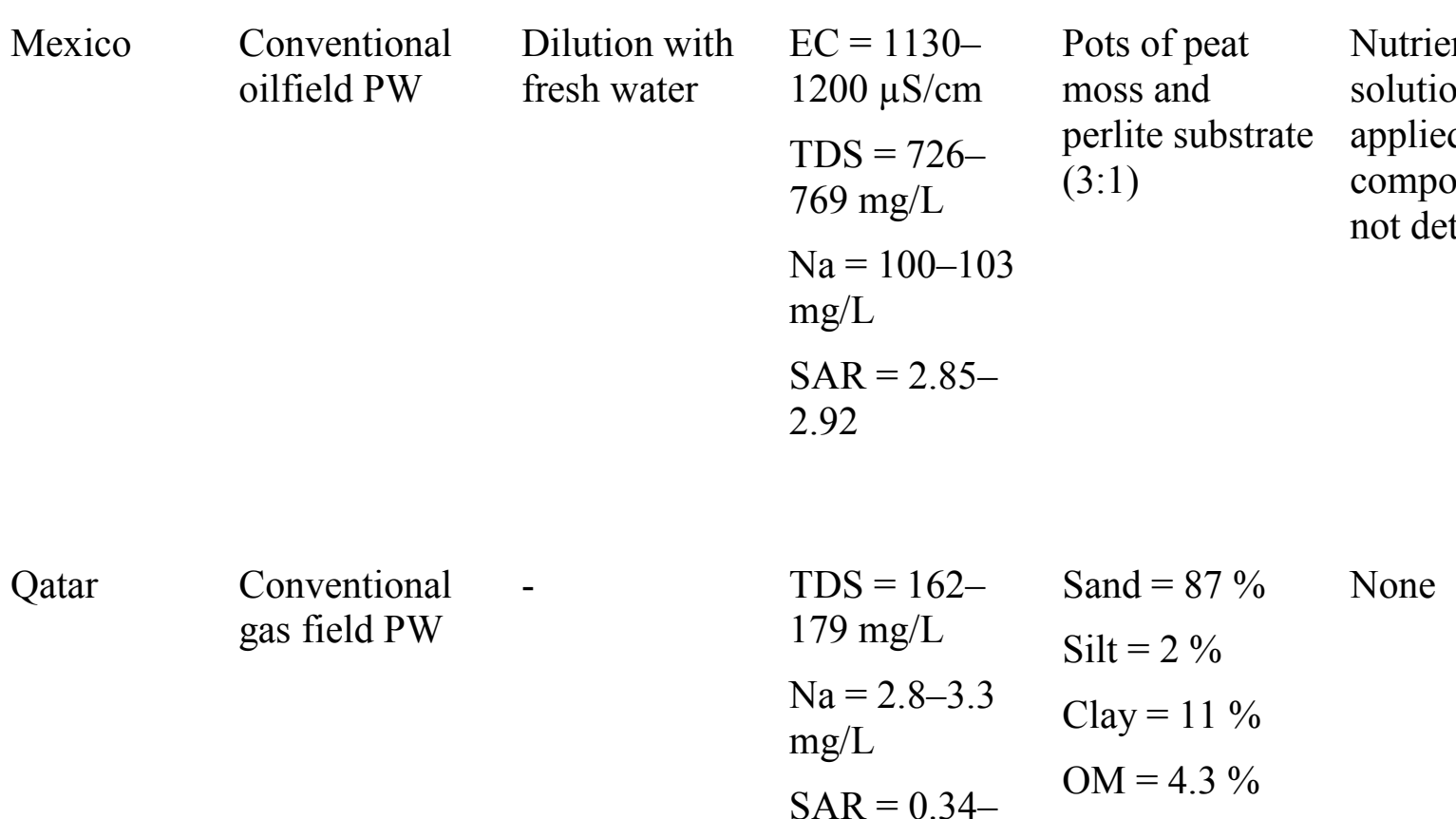

Tomato

Raw PW is unsuitable for irrigation due to the high levels of EC.

Diluted PW with fresh water to adjust the EC to $1500 \mu \mathrm{S} / \mathrm{cm}$ is suitable for irrigation of tomato under greenhouse conditions.

The fresh weight of the plant was significantly reduced at irrigation with gas PW. Crude fiber was significantly higher. 


\begin{tabular}{|c|c|c|c|c|c|c|c|c|}
\hline $\begin{array}{l}\text { Country } \\
\text { (Region) }\end{array}$ & $\begin{array}{l}\text { Type of O\&G } \\
\text { field associated } \\
\text { to the PW used }\end{array}$ & $\begin{array}{l}\text { Water } \\
\text { treatment }\end{array}$ & $\begin{array}{l}\text { Quality of the } \\
\text { water applied }\end{array}$ & Soil type & $\begin{array}{l}\text { Soil } \\
\text { amendments } \\
\text { applied }\end{array}$ & Crop irrigated & Main observations & Ref. \\
\hline & & & 0.35 & & & & \multirow{2}{*}{\multicolumn{2}{|c|}{$\begin{array}{l}\text { Gas PW can result in } \\
\text { a reasonable } \\
\text { production with } \\
\text { acceptable quality. }\end{array}$}} \\
\hline & & & $\begin{array}{l}\mathrm{EC}=270-300 \\
\mu \mathrm{S} / \mathrm{cm}\end{array}$ & & & & & \\
\hline Yemen & $\begin{array}{l}\text { Conventional } \\
\text { oilfield PW }\end{array}$ & $\begin{array}{l}\text { Constructed } \\
\text { wetland (reed } \\
\text { bed) }\end{array}$ & $\begin{array}{l}\mathrm{NaCl}=15000 \\
\mathrm{mg} / \mathrm{L}\end{array}$ & Clayed-sandy & None & $\begin{array}{l}\text { Cotton and } \\
\text { hemp }\end{array}$ & $\begin{array}{l}\text { Hemp was affected by } \\
\text { salinity but not cotton }\end{array}$ & 13 \\
\hline
\end{tabular}

${ }^{1}$ (Jackson and Myers, 2002); ${ }^{2}$ (Burkhardt et al., 2015); ${ }^{3}$ (Mullins and Hajek, 1998); ${ }^{4}$ (Cawelo Water District, 2015); ${ }^{5}$ Heberger and Donnelly, 2015); ${ }^{6}$ Robles, 2016); ${ }^{7}$ (Breuer, 2017); ${ }^{8}$ (Breuer, 2011); ${ }^{9}$ (Sluijterman et al., 2004); ${ }^{10}$ (Hirayama et al., 2002); ${ }^{11}$ (Martel-Valles et al., 2014); ${ }^{12}$ (Ibrahim et al., 2009); ${ }^{13}$ (Rambeau et al., 2004) 
5.2 Agro-environmental risks associated with irrigation with oil and gas produced water

The concentration ranges of salts (measured through TDS and EC) particularly sodium and some heavy metals $(\mathrm{Al}-\mathrm{Zn})$ are very often over the values recommended by the FAO guidelines that we use as a reference for the quality of irrigation water (Table 2) (Alley et al., 2011; Ayers and Westcot, 1985). These components remain in high concentration even after conventional treatment, which mainly targets organic pollutants (Fakhru'l-Razi et al., 2009). The other components of PW represent lower risks to the soil because they are either initially present in low concentrations (e.g. nutrients and radioactive elements) or their concentrations are highly reduced during treatment processes and are particularly targeted by regulation (e.g. hydrocarbons) (Fakhru'l-Razi et al., 2009). Thus, hydrocarbons represent a minor hazard for soil compared to salts and heavy metals. Indeed, oil and grease concentration in most documented PW is quite low compared to US EPA standards for agricultural use of PW (Table 2). PW that could be reused at a large scale would otherwise be disposed or discharged into the environment and would therefore be treated up to tertiary level, having a final oil and grease concentration below $10 \mathrm{mg} / \mathrm{L}$ (SPE, 2011); which is also below US EPA standards. In addition, hydrocarbons do not tend to accumulate in the long term as salts or metals do, this is because of their organic nature enabling biological degradation in soil (Pichtel, 2016).

As a result, the challenging components of PW remain in dissolved formation minerals (i.e. salts and sodium) and metalloids. If PW is used in agricultural irrigation, these elements can accumulate in the soil; creating risks of soil salinisation and sodification as observed in most case studies (Table 4). These risks are not specific to PW but they are also related to irrigation with both municipal and industrial wastewaters that are often saline and sodic (Elgallal et al., 2016; Maassen, 2016).

5.2.1 Risks related to the salinity and sodicity of produced water 
Generally, salinity and sodicity are closely linked because the main ions in PW are sodium $\left(\mathrm{Na}^{+}\right)$and chloride $\left(\mathrm{Cl}^{-}\right)$. Other cations such as $\mathrm{K}^{+}, \mathrm{Ca}^{2+}, \mathrm{Mg}^{2+}, \mathrm{Ba}^{2+}, \mathrm{Sr}^{2+}, \mathrm{Fe}^{2+}$ and anions like $\mathrm{SO}_{4}{ }^{2-}, \mathrm{CO}_{3}{ }^{2-}, \mathrm{HCO}_{3}{ }^{-}$also affect $\mathrm{PW}$ salinity and buffering capacity (Hansen and Davies, 1994), but at a lower scale than $\mathrm{Na}^{+}$and $\mathrm{Cl}^{-}$due to lower concentrations in PW. However, on some sites that use seawater for enhanced oil recovery, $\mathrm{SO}_{4}{ }^{2-}$ concentration is high and contribute significantly to PW salinity (Neff, 2002). The salt concentration of most PW varies from 1000 to $300000 \mathrm{mg} / \mathrm{L}$ classifying it between 'slightly saline' to 'brine' (Jacobs et al., 1992; Rhoades et al., 1992).

The misuse of PW in irrigation can increase soil salinity and sodicity to unsustainable levels for crops and soil's health even on a short term (Burkhardt et al., 2015; Hirayama et al., 2002; Rambeau et al., 2004) (Table 4)Table 4.

Excessive salinity and sodicity of PW used for irrigation can dramatically and irreversibly alter soil structure in drylands. Salt accumulates in soil, particularly in the root zone, as a result of high rates of evaporation and low precipitation (Burkhardt et al., 2015; Elgallal et al., 2016; Safriel et al., 2006). The build-up of salt could lead to elevated levels of exchangeable sodium and SAR in soil if $\mathrm{Na}^{+}$is dominant ion (Ayers and Westcot, 1985; Beletse et al., 2008; Johnston et al., 2008; Stefanakis, 2016; Toze, 2006) causing a decrease in water infiltration and dispersion of clay which destroys clay-humus complex and finally lead to possible nutrient deficiencies, such as $\mathrm{Ca}$ and $\mathrm{Mg}$, which are displaced by the high $\mathrm{Na}$ content, or unavailable because the roots cannot penetrate into the subsurface (Hillel, 2004). A vicious circle can set up once soils are sodic. Indeed, when sodic soils are wet, they become sticky, and when they dry, they form a crusty layer that is nearly impermeable. Then more water is lost due to evaporation or runoff and salts accumulate even more in the topsoil, this worsens salinity and sodicity problems. Elevated salinity affects the ability of plants to 
take up water to facilitate biochemical processes such as photosynthesis and plant growth (Vance et al., 2004).

For example, a 2-year study conducted in the Powder River Basin (USA) showed that irrigation with untreated CBM PW increased soil sodicity from 1.4 to $2.8 \mathrm{mmol} / \mathrm{L}$ (measured on a saturated extract) while concentrations of $\mathrm{Ca}$ and $\mathrm{Mg}$ decreased, $\mathrm{Na}$ concentration increased reaching levels that are potentially toxic to the crop (Burkhardt et al., 2015). Another study in the same area showed that CBM PW increased the soil EC about two-fold compared to pre-irrigation level (Johnston et al., 2008). Similar results were observed in Alabama (USA) where CBM PW was used continuously for 30 days to irrigate sorghum and sudangrass. The exchangeable Na percentage reached $40 \%$ indicating that long-term use of CBM PW could lead to degradation of soil physical properties (Mullins and Hajek, 1998). In Oman, irrigation with conventional oilfield PW increased soil EC from 1.63 to $7.08 \mathrm{dS} / \mathrm{m}$ after 102 days of irrigation although fresh water was used at a regular frequency (28 days totally) to leach salts, in the meantime, the SAR increased dramatically from 2.31 to 68.10 (Hirayama et al., 2002).

\subsubsection{Risks related to heavy metals of produced water}

Metalloids are generally studied because of their impact on human health and on the environment, although some metals such as boron are known to be phytotoxic at high concentration and are therefore an agronomic issue too (Qadir and Drechsel, 2016; Tal, 2016). Heavy metals do not biodegrade like organic pollutants, they chemically and physically interact with naturally occurring substances, which alter their mobility. In fact, some heavy metals are adsorbed, or bound to other particles, reducing their chance of migration or absorption into plants. The degree to which different heavy metals are immobilised in the soil is determined by the natural composition of the soil, $\mathrm{pH}$, water content, and temperature (Dube et al., 2001) although still not completely documented 
(Pedrero et al., 2010). Heavy metals concentrate in plants (particularly leafy vegetables) and can transfer into the food chain posing a threat to humans (Farrag et al., 2016; Rattan et al., 2005). There is evidence of accumulation of $\mathrm{Cu}$ and $\mathrm{Zn}$ in soil using $\mathrm{PW}$ for irrigation in Qatar (Ibrahim et al., 2009).

\subsection{Adapting produced water to irrigation}

From an agronomic perspective, soil salinisation and sodification are critical as they can immediately impact soil structure and fertility because of the high loads of salt brought by irrigation with saline-sodic PW. In contrast, heavy metals concentrations in PW may create problems of toxicity to plants over a longer term (Table 2). Therefore, in order to use PW for irrigation in dry areas, the water salinity and sodicity have to be within the suitable EC-SAR ranges described in Table 2. Figure 2 shows that a limited proportion of PW can be used without reduction of their salinity (EC) and sodicity (SAR), indeed, over 474 samples of PW collected in the USA, Australia, South Africa and Qatar, only $8.4 \%$ of PW samples meet the requirements for being used in irrigation, of which only $10 \%$ meet the requirements for unrestricted irrigation.

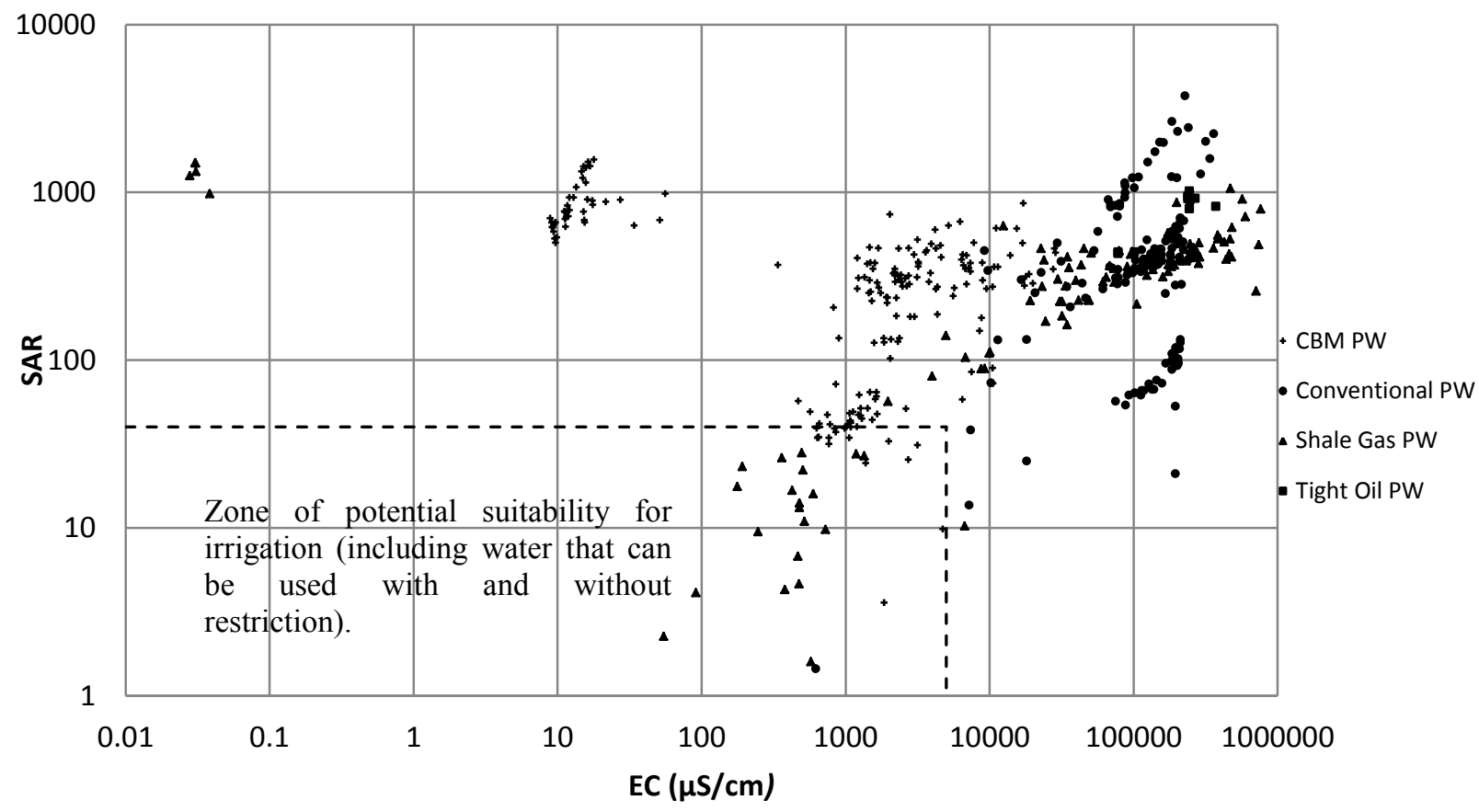


Figure 2. Sodicity (SAR) and salinity (EC) of 474 samples of PW associated to different hydrocarbon types (CBM, conventional shale gas and tight oil) compared to irrigation water quality guidelines based on salinity and sodicity hazard adapted from (ALL Consulting, 2003; Ayers and Westcot, 1985; Beletse et al., 2008; Brown et al., 2010; Burkhardt et al., 2015; Dresel and Rose, 2010; Ganjegunte et al., 2005; Jackson and Myers, 2002; Janson et al., 2015; Johnston et al., 2007; Mullins and Hajek, 1998; Myers, 2014; Szép and Kohlheb, 2010; USGS, 2016; Xu et al., 2008).

Although most PW cannot be sustainably used for irrigation, there are solutions for reducing EC and SAR of PW in order to use it for irrigation. Blending of PW with low salinity freshwater and PW desalination using reverse osmosis are the two principal solutions commonly cited in the literature (Fisher et al., 2010; Guerra et al., 2011; Hagstrom et al., 2016; Jakubowski et al., 2013; Sullivan Graham et al., 2015; Xu et al., 2008).

In California, the oil firm Chevron supplies Cawelo Water District with 44 million $\mathrm{m}^{3}$ of treated PW which is then blended with fresh water to irrigate18,600 ha of food crops (Arnold et al., 2004; Heberger and Donnelly, 2015; Martel-Valles et al., 2016). Another study in the Powder River Basin (USA) showed that PW is suitable for irrigation when mixed with fresh water in 1:3 ratio (Burkhardt et al., 2015). PW blending does not necessarily require a source of high-quality freshwater. Treated municipal sewage, for example, can be mixed with PW to obtain water suitable for irrigation.

Desalination can also be used to reduce PW salinity and sodicity. In the USA, CBM PW has been treated to irrigation standards using ultra-low pressure reverse osmosis (ULPRO) at an estimated cost of USD $0.24 / \mathrm{m}^{3}$ (Xu et al., 2008). Although desalination cost has always been a limitation for using desalinated water in irrigation, the value of water resources increases with water scarcity (Maton et al., 2010). Thus, in dry regions with developed economies, such as the Gulf States, Israel and Spain, desalination could be justified for highvalue crops (Burn et al., 2015). Moreover, treating relatively low salinity PW instead of more 
saline alternatives (e.g. brackish groundwater or seawater) might be economic (Kaner et al., 2017; Qadir et al., 2007).

In addition to reducing the salinity and sodicity of PW, soil and crop management can be adapted to be more resilient against the risks of soil salinisation and sodification. Selecting salt-tolerant crops was found to be the principal factor for the sustainability of wastewater irrigation (Ayers and Westcot, 1985; Maas and Grattan, 1999). Suitable crops should also demonstrate a good marketing value in order to compensate the associated costs of using PW (Fonseca et al., 2007).

Soil ameliorants help to counter undesirable effects of salinity and sodicity of PW. In fact, irrigation with $\mathrm{PW}$ in combination with gypsum $\left(\mathrm{CaSO}_{4}\right)$ and sulphur increase the sulphate content of the soil, helping to mitigate soil dispersion by $\mathrm{Na}^{+}$(Johnston et al., 2008). These soil ameliorants individually and/or in combination are used in Australia and in the USA for CBM PW application to agricultural croplands and grasslands (Biggs et al., 2012; Fisher et al., 2010). Gypsum is used as a surface soil ameliorant to increase the level of $\mathrm{Ca}^{2+}$ in the system (Amezketa et al., 2005; Guerra et al., 2011; Mace et al., 1999). Sulphur is used as a surface soil ameliorant to decrease soil $\mathrm{pH}$ and enhance calcite $\left(\mathrm{CaCO}_{3}\right)$ dissolution to release $\mathrm{Ca}^{2+}$ into the soil solution to counter $\mathrm{Na}^{+}$(Johnston et al., 2008). The addition of significant organic amendments such as poultry manure (rich in calcium) can contribute to re-balance the SAR (Pichtel, 2016). Other types of soil improvers may prove to be beneficial in treating soil irrigated with PW. For example, use of synthetic polymers (e.g., polyacrylamides) to stabilise aggregates has proved to be successful in improving the physical properties of sodic soils (Alberta Environmental Sciences Division, 2001; Sumner, 1993).

Soil dilution may relieve salinity problems following the release of PW. Indeed, in arid and semi-arid climates, contaminants tend to accumulate in the topsoil. Mixing of the less- 
contaminated deeper soil with the surface soil can result in dilution of contaminants (Wolf et al., 2015).

Leaching salts below the root zone helps to control soil salinity. It also contributes to the restoration of the SAR to a suitable range of values by leaching excess sodium (Johnston et al., 2008). The volume of water and the frequency of leaching fractions depend on the PW quality, crop and climate.

Combining leaching and soil ameliorants (sulphur burners) has been proved to be efficient to stabilise soil sodicity when CBM PW has been used for irrigation (Vance et al., 2004).

\section{Conclusion}

A significant part of current and forecast volumes of PW will be produced in drylands where water scarcity demands alternative irrigation water sources. PW could be an effective resource in drylands; indeed, at the global scale, about $45 \%$ of PW is discharged, disposed of, or not reused in a beneficial way. However, quality remains the principal challenge for the reuse of this massive quantity of PW in irrigation. In fact, most PW are high in salts ([TDS] = $35-472000 \mathrm{mg} / \mathrm{L})$ and sodium $([\mathrm{Na}]=3-435000 \mathrm{mg} / \mathrm{L})$. As a consequence, the main risks for the soil of using PW in irrigation are soil salinisation and sodification as observed in the reviewed experiences of irrigation with PW. Nonetheless, these issues are not unique to PW, and dryland farming is often prone to challenges in soil salinity management.

Of the PW samples from around the world summarised in this paper, only a limited proportion (8.4\%) were potentially suitability for irrigation in terms of EC-SAR, and for most PW, water treatment, water blending and/or farm-based management techniques would be required to mitigate the risks of soil degradation. The costs of achieving the desired water quality will be very site-specific and will depend, for example, on the PW quality, the cost of energy, and the opportunity cost and availability of alternative water supplies. Similarly, the benefit of using PW for irrigation will depend on the local market for the crop produced and 
cost of alternative PW disposal methods. However, in arid areas, where alternative water sources are not available and where the desalination industry is well established with competitive costs, using treated PW to produce and economic output may provide social, economic and environmental advantages over alternative methods of disposal.

Although well-documented studies exist, they are often limited to particular cases (e.g. field experiments in specific locations with their specific soils, climates and economic backgrounds) and cannot easily be extrapolated to world drylands. Also, the reuse of PW for the irrigation of food crops is still not widely considered compared to non-food crops, although food crops could be a resource of primary interest in drylands. Further integrated research is necessary regarding the understanding of the sustainability of food crop irrigation with PW in drylands including its economic feasibility. 


\section{Acknowledgment}

This work was made possible by the support of a National Priorities Research Programme (NPRP) grant from the Qatar National Research Fund (QNRF), grant reference number NPRP8-

1115-2-473. The statements made herein are solely the responsibility of the authors.

\section{References}

Abousnina, R.M., Nghiem, L.D., Bundschuh, J., 2015. Comparison between oily and coal seam gas produced water with respect to quantity, characteristics and treatment technologies: A review. Desalin. Water Treat. 54, 1793-1808.

Ahan, J.A., 2014. Characterization of produced water from two offshore oil fields in Qatar. MSc thesis, Qatar Univiversity. doi:10.1007/s13398-014-0173-7.2. Available at: http:/quspace.qu.edu.qa/bitstream/handle/10576/3287/Ahan, Jumana Ahmad.pdf (accessed 18.04.18).

Al-Haddabi, M., Vuthaluru, H., Mushtaque, A., Znad, H., 2015. Use of Ceramic Membrane Technology for Sustainable Management of Oil Production Water: A Review, in: Baawain, M., Choudri, B.., Ahmed, M., Purnama, A. (Eds.), Recent Progress in Desalination, Environmental and Marine Outfall Systems. Springer International Publishing, New York, pp. 11-24. doi:10.1007/978-3-319-19123-2

Al-Mahrooqi, M.A., Marketz, F., Hinai, G., 2007. Improved well and reservoir management in horizontal wells using swelling elastomers, in: SPE Annual Technical Conference and Exhibition. Society of Petroleum Engineers, Anaheim, pp. 1-8.

Alanezi, Y.H.., 2016. Cross-flow microfiltration of synthetic oily wastewater using multichannel ceramic membrane, in: Ismail, A.F., Matsuura, T. (Eds.), Membrane Technology for Water and Wastewater Treatment, Energy and Environment. CRC Press, London, pp. 
$71-83$.

Alberta Environmental Sciences Division, 2001. Salt Contamination Assessment and Remediation Guidelines. Edmonton. doi:10.1007/s13398-014-0173-7.2. Available at: http://archive.org/details/saltcontaminatio00albe (accessed 18.04.18).

ALL Consulting, 2003. Handbook on Coal Bed Methane Produced Water: Management and Beneficial Use Alternatives. Ground Water Protection Research Foundation, U.S. Department of Energy, National Petroleum Technology Office, Bureau of Land Management. Tulsa. $\quad$ Available at: http://www.gwpc.org/elibrary/documents/general/Coalbed Methane Produced Water Management and Beneficial Use Alternatives.pdf (accessed 18.04.18).

Alleman, D., 2011. Treatment of shale gas produced water for discharge. Presentation at the EPA Technical Workshops for the Hydraulic Fracturing Study -Water Resources Management, Washington D.C., March 29-30. Available at: http://www.epa.gov/hfstudy/17_Alleman__Produced_Water_508.pdf(accessed 18.04.18).

Alley, B., Beebe, A., Rodgers, J., Castle, J.W., 2011. Chemical and physical characterization of produced waters from conventional and unconventional fossil fuel resources. Chemosphere $85,74-82$.

Amezketa, E., Aragüés, R., Gazol, R., 2005. Efficiency of sulfuric acid, mined gypsum, and two gypsum by-products in soil crusting prevention and sodic soil reclamation. Agron. J. 97, 983-989.

Arnold, R., Burnett, D.B., Elphick, J., Feeley III, T.J., Galbrun, M., Hightower, M., Jiang, Z., Khan, M., Lavery, M., Luffey, F., Verbeek, P., 2004. Managing Water - From Waste to Resource. Oilf. Rev. 16, 26-41. 
Ayers, R.S., Westcot, D.W., 1985. Water quality for agriculture. Food and Agricultural Organization (FAO). Irrig. Drain. Pap. 29, 174.

Barrow, C.., 1992. World atlas of desertification. United Nations Environment Programme (UNEP), Land Degradation and Development. Wiley-Blackwell, London. doi:10.1002/1dr.3400030407

Beletse, Y.G., Annandale, J.G., Steyn, J.M., Hall, I., Aken, M.E., 2008. Can crops be irrigated with sodium bicarbonate rich CBM deep aquifer water? Theoretical and field evaluation. Ecol. Eng. 33, 26-36.

Biggs, A., Witheyman, S., Williams, K., Cupples, N., 2012. Assessing the salinity impacts of coal seam gas water on landscapes and surface streams. Final Report of Activity 3 of the Healthy HeadWaters Coal Seam Gas Water Feasibility Study. Department of Natural Resources and Mines, Toowoomba. Available at: http://www.protectlimestonecoast.org.au/wp-content/uploads/2015/01/water-salinity-csgheadwaters.pdf (accessed 18.04.18).

Blackam, M., 2017. The relationship between energy and water in unconventional gas: Source, fate and water-energy intensity. Available at: http://www.coffey.com/en/ingenuitycoffey/water-and-energy-in-unconventional-gas (accessed 18.04.18).

BP, 2017. British Petroleum (BP) Energy Outlook 2017 edition: data tables [WWW Document]. URL http:/www.bp.com/en/global/corporate/energy-economics/energy-outlook/energyoutlook-downloads.html (accessed 3.8.17).

Breuer, R., 2017. Nimr Water Treatment Plant, in: Produced Water Workshop. NEL, Aberdeen, p. 14. Available at: http://www.tuvnel.com/site2/subpage/pww2017pres (accessed 18.04.18). 
Breuer, R., 2011. Produced water treatment using wetlands - Reducing the environmental impact of oilfield operations. SPE European Health, Safety and Environmental Conference in Oil and Gas Exploration and Production, 22-24 February, Vienna, Austria. Available at: http://doi.org/10.2118/140124-MS (accessed 18.04.18).

Brown, T., Morris, J., Richards, P., Mason, J., 2010. Effects of Irrigating with Treated Oil and Gas Product Water on Crop Biomass and Soil Permeability: Final Technical Report. Pittsburgh. doi:10.2172/1007996. Available at: http://www.osti.gov/servlets/purl/1007996NS1Xsy/ (accessed 18.04.18).

Burkhardt, A., Gawde, A., Cantrell, C.L., Baxter, H.L., Joyce, B.L., Stewart, C.N., Zheljazkov, V.D., 2015. Effects of produced water on soil characteristics, plant biomass, and secondary metabolites. J. Environ. Qual. 44, 1938-1947.

Burn, S., Hoang, M., Zarzo, D., Olewniak, F., Campos, E., Bolto, B., Barron, O., 2015. Desalination techniques - A review of the opportunities for desalination in agriculture. Desalination 364, 2-16.

Burnett, D.B., 2004. Potential for beneficial use of oil and gas produced water, Global Petroleum Institute, Texas Water Resources Institute.

Cawelo Water District, 2015. 2015 Agricultural Water Management Plan. Bakersfield. Available at: http://www.water.ca.gov/wateruseefficiency/sb7/docs/2016/Cawelo WD 2016 AWMP.pdf (accessed 18.04.18).

CGIAR, 2015. Assessing the importance of agricultural and tree biodiversity in dryland $\begin{array}{llll}\text { production } & \text { systems } & \text { [WWW } & \text { Document }] .\end{array}$ http://www.bioversityinternational.org/news/detail/assessing-the-importance-ofagricultural-and-tree-biodiversity-in-dryland-production-systems/ (accessed 3.8.17). 
Clark, C., Veil, J., 2015. U.S. Produced Water Volumes and Management Practices in 2012, $\begin{array}{llll}\text { Groundwater } & \text { Protection } & \text { Council. }\end{array}$ http://www.gwpc.org/sites/default/files/Produced Water Report 2014-GWPC_0.pdf (accessed 18.04.18).

Clark, C.E., Veil, J., 2009. Produced Water Volumes and Management Practices in the United States, Argonne National Laboratory. Argonne. doi:10.2172/1007397. Available at: http://www.ipd.anl.gov/anlpubs/2009/07/64622.pdf (accessed 18.04.18).

Commonwealth of Australia, 2014. Co-produced Water: Risks to Aquatic Ecosystems, Background review. Canberra. Available at: http://www.environment.gov.au/water/coaland-coal-seam-gas/publications/background-review-co-produced-water (accessed 18.04.18).

Dal Ferro, B., Smith, M., 2007. Global Onshore and Offshore Water Production. Oil Gas Rev. OTC Ed. 34-36.

Deng, S., Yu, G., Chen, Z., Wu, D., Xia, F., Jiang, N., 2008. Characterization of suspended solids in produced water in Daqing oilfield. Colloids Surfaces A Physicochem. Eng. Asp. $332,63-69$.

Digital H2O, 2015. Produced water disposal trends in the permian basin. Presentation. Available at: $\quad$ http://www.lbcg.com/media/downloads/events/615/pp17-piers-wells.11331.pdf (accessed 18.04.18).

Dresel, P., Rose, A., 2010. Chemistry and origin of oil and gas well brines in western Pennsylvania, Pennsylvania Geol. Surv., 4th series. Harrisburg. doi:Open-File Report OFOG 1001.0

Dube, A., Zbytniewski, R., Kowalkowski, T., Cukrowska, E., Buszewski, B., 2001. Adsorption 
and migration of heavy metals in soil. Polish J. Environ. Stud. 10, 1-10.

EIA, United States Energy Information Administration (EIA) [WWW Document], 2016. URL http://www.eia.gov/beta/international/rankings/\#?prodact=53-

$1 \& c y=2015 \&$ pid=53\&tl_type=a\&aid=1\&tl_id=1-A (accessed 3.8.17).

Ekins, P., Vanner, R., Firebrace, J., 2007. Zero emissions of oil in water from offshore oil and gas installations: Economic and environmental implications. J. Clean. Prod. 15, 1302-1315.

El-Zanfaly, H.T., 2015. Wastewater reuse in agriculture: A way to develop the economies of arid regions of the developing countries. J. Environ. Prot. Sustain. Dev. 1, 144-158.

Elgallal, M., Fletcher, L., Evans, B., 2016. Assessment of potential risks associated with chemicals in wastewater used for irrigation in arid and semiarid zones: A review. Agric. Water Manag. 177, 419-431.

Engle, M.A., Cozzarelli, I.M., Smith, B.D., 2014. USGS investigations of water produced during hydrocarbon reservoir development. Available at: http://pubs.usgs.gov/fs/2014/3104/ (accessed 18.04.18).

Fakhru'l-Razi, A., Pendashteh, A., Abdullah, L.C., Biak, D.R.A., Madaeni, S.S., Abidin, Z.Z., 2009. Review of technologies for oil and gas produced water treatment. J. Hazard. Mater. $170,530-551$.

FAO, 2016. Trees, forests and land use in drylands: The first global assessment. Rome. Available at: http://www.fao.org/3/a-i5905e.pdf (accessed 18.04.18).

Farrag, K., Elbastamy, E., Ramadan, A., 2016. Health risk assessment of heavy metals in irrigated agricultural crops, El-Saff wastewater canal, Egypt. Clean - Soil, Air, Water 44, $1174-1183$.

Feng, S., Fu, Q., 2013. Expansion of global drylands under a warming climate. Atmos. Chem. 
Phys. 13, 10081-10094.

Fisher, W.L., Bauder, J.W., Clements, W.H., Hua, I., Maest, A.S., Ray, A.W., Riese, W., Siegel, D.I., Thyne, G., 2010. Management and Effects of Coalbed Methane Produced Water in the United States. National Academies Press, Washington D.C. Available at: http://www.nap.edu/catalog/12915/management-and-effects-of-coalbed-methane-producedwater-in-the-western-united-states (accessed 18.04.18).

Fonseca, A.F. da, Herpin, U., Paula, A.M. de, Victória, R.L., Melfi, A.J., 2007. Agricultural use of treated sewage effluents: agronomic and environmental implications and perspectives for Brazil. Sci. Agric. 64, 194-209.

Freyman, M., 2014. Hydraulic Fracturing and Water Stress: Water Demand by the Numbers. Ceres, Boston. Available at: http://www.ceres.org/resources/reports/hydraulic-fracturingwater-stress-water-demand-numbers (accessed 18.04.18).

Galbraith, K., 2013. Fracking increase spurs fears over water use [WWW Document]. Texas Trib. URL http://www.texastribune.org/2013/03/08/texas-water-use-fracking-stirs-concerns/ (accessed 3.8.17).

Ganjegunte, G.K., Vance, G.F., King, L.A., 2005. Tracking salt and sodium build up due to irrigation with coalbed natural gas product water: Soil solution lysimeter and soil saturated paste extract studies. J. Am. Soc. Min. Reclam. 378-387.

Garland, E., 2005. Environmental regulatory framework in Europe: An update, in: SPE/EPA/DOE Exploration and Production Environmental Conference. Society of Petroleum Engineers, Galveston, pp. 1-10.

Gassert, F., Landis, M., Luck, M., Reig, P., Shiao, T., 2014. Aqueduct global maps 2.1: Constructing decision-relevant global water risk indicators, World Resources Institute. 
http://www.wri.org/sites/default/files/Aqueduct_Global_Maps_2.1.pdf (accessed 18.04.18).

Global Water Intelligence, 2014. Water for offshore oil and gas 122. Available at: http://www.globalwaterintel.com/client_media/uploaded/Chantal/Water_for_Offshore_Oil_ and_Gas_Sample_pages.pdf (accessed 18.04.18).

Gordon, D., 2015. The abundance of oils in the water-stressed Rockies [WWW Document]. Carnegie Endow. Int. Peace. URL http://carnegieendowment.org/2015/01/05/abundance-ofoils-in-water-stressed-rockies-pub-57637 (accessed 3.8.17).

Gratzfeld, J., 2003. Introduction, in: Gratzfeld, J. (Ed.), Extractive Industries in Arid and SemiArid Zones: Environmental Planning and Management. IUCN, Gland, pp. 6-9. doi:10.2305/IUCN.CH.2004.CEM.1.en

Guerra, Dahm, K., Dundorf, S., 2011. Oil and Gas Produced Water Management and Beneficial Use in the Western United States, Reclamation. Denver. doi:3180. Available at: http://www.usbr.gov/research/dwpr/reportpdfs/report157.pdf (accessed 18.04.18).

Gulf Intelligence, 2016. Produced water: Five key recommendations [WWW Document]. URL http://www.thegulfintelligence.com/Docs.Viewer/6138f24c-a23c-43e2-8270793ec8a51dfd/default.aspx (accessed 3.8.17).

Hagstrom, E.L., Lyles, C., Pattanayek, M., DeShields, B., Berkman, M.P., 2016. Produced water: Emerging challenges, risks, and opportunities. Environ. Claims J. 28, 122-139.

Hansen, B., Davies, S., 1994. Review of potential technologies for the removal of dissolved components from produced water. Chem. Eng. Res. Des. 72, 176-188.

Healy, R.W., Alley, W.M., Engle, M.A., McMahon, P.B., Bales, J.D., 2015. The Water-Energy Nexus: An Earth Science Perspective: U.S. Geological Survey Circular 1407. USGS, 
Reston. doi:10.3133/cir1407

Heberger, M., Donnelly, K., 2015. Oil, Food, and Water: Challenges and Opportunities for California Agriculture. Oakland. Available at: http://pacinst.org/wpcontent/uploads/2015/12/PI_OilFoodAndWater_.pdf (accessed 18.04.18).

Hillel, D., 2004. Chapter 9: Solute Movement and Soil Salinity, in: Introduction to Environmental Soil Physics. Elsevier Academic Press, San Diego, pp. 167-186. doi:10.1017/CBO9781107415324.004

Hirayama, A., Maegaito, M., Kawaguchi, M., Ishikawa, A., Sueyoshi, M., Al-Bemani, A.S., Mushtaque, A., Esechie, H., Al-Mazrui, S.A., Al-Haddabi, M.H., Al-Khanjari, S.S., 2002. Omani oil fields produced water: Treatment and utilization, in: SPE International Petroleum Conference and Exhibition in Mexico. Society of Petroleum Engineers, Villahermosa.

Hitaj, C., Boslett, A., Weber, J.G., 2014. Shale development and agriculture. Choices 29, 1-7. Available at: http://choicesmagazine.org/choices-magazine/theme-articles/is-the-naturalgas-revolution-all-its-fracked-up-to-be-for-local-economies/shale-development-andagriculture (accessed 18.04.18).

Hladik, M.L., Focazio, M.J., Engle, M., 2014. Discharges of produced waters from oil and gas extraction via wastewater treatment plants are sources of disinfection by-products to receiving streams. Sci. Total Environ. 466-467, 1085-1083.

Ibrahim, Y., Marroff, A., Wafi, M., 2009. Effect of irrigation with gas produced water enriched with $\mathrm{CO}_{2}$ on alfalfa growth, quality and mineral content. J.Sc. Tech 10, 36-46.

IEA, 2013. World Energy Outlook 2013, 2nd ed, International Energy Agency (IEA). IEA Publications, Paris. doi:10.1787/20725302

IESC, 2014. Coal seam gas extraction and co-produced water, fact sheet, Independent Expert 
Scientific Committee on Coal Seam Gas and Large Coal Mining Development. Available at: http://www.iesc.environment.gov.au/publications/csg-extraction-and-co-produced-water (accessed 18.04.18).

Igunnu, E.T., Chen, G.Z., 2014. Produced water treatment technologies. Int. J. Low-Carbon Technol. 9, 157-177.

IOGP, 2014. Environmental Performance Indicators: 2014 Data. International Association of Oil and Gas Producers (IOGP). London. Available at: http://www.iogp.org/bookstore/theme/environmental-performance-indicators/ (accessed 18.04.18).

Jackson, L., Myers, J., 2002. Alternative use of produced water in aquaculture and hydroponic systems at Naval Petroleum Reserve No. 3. Aquaculture 3, 1-11. Available at: http://www.gwpc.org/sites/default/files/event-sessions/Lorri_Jackson_PWC2002_0.pdf (accessed 18.04.18).

Jacobs Consultancy, 2010. Estimating crude oil production carbon intensity. Presentation at the $\begin{array}{llll}\text { California Air } & \text { Resources }\end{array}$ http://www.arb.ca.gov/fuels/lcfs/lcfs_meetings/050610jacobs-prstn.pdf (accessed 18.04.18).

Jacobs, R.P.W.M., Grant, R.O.H., Kwant, J., Marquenie, J.M., Mentzer, E., 1992. The composition of produced water from Shell operated oil and gas production in the North Sea, in: Ray, J.P., Engelhardt, F.R. (Eds.), Produced Water: Technological Environmental Issues and Solutions. Plenum Press, San Diego, pp. 13-21. doi:10.1007/978-1-4615-2902-6_2

Jakubowski, R., Haws, N., Ellerbroek, D., Murtagh, J., Macfarlane, D., 2013. Development of a management tool to support the beneficial use of treated coal seam gas water for irrigation in Eastern Australia. Mine Water Environ. 33, 133-145. 
Janson, A., Katebah, M., Santos, A., Minier-Matar, J., Hussain, A., Adham, S., Judd, S., 2015. Assessing the biotreatability of produced water from a Qatari gas field, in: International Petroleum Technology Conference. Doha, pp. 1113-1119.

Johnston, C.R., Vance, G.F., Ganjegunte, G., 2007. Changes in soil physical and chemical properties of a cropland irrigated with CBNG co-produced water, in: National Meeting of the American Society of Mining and Reclamation. American Society of Mining and Reclamation, Gillette, pp. 350-372. doi:10.21000/JASMR07010350

Johnston, C.R., Vance, G.F., Ganjegunte, G.K., 2008. Irrigation with coalbed natural gas coproduced water. Agric. Water Manag. 95, 1243-1252.

Kaner, A., Tripler, E., Hadas, E., Ben-Gal, A., 2017. Feasibility of desalination as an alternative to irrigation with water high in salts. Desalination 416, 122-128. doi:10.1016/j.desal.2017.05.002

Keesom, W., Unnasch, S., Moretta, J., 2009. Life Cycle Assessment Comparison of North American and Imported Crudes. Alberta Energy Research Institute, Chicago. Available at: http://climateactionnetwork.ca/2009/07/18/09-07-jacobs-consultancy-life-cycle-assessmentcomparison-of-north-american-and-imported-crudes/ (accessed 18.04.18).

Khan, S., Kordek, G., 2013. Coal Seam Gas : Produced Water and Solids. Prepared for the Office of the New South Wales Chief Scientist and Engineer (OCSE). Available at: http://www.chiefscientist.nsw.gov.au/_data/assets/pdf_file/0017/44081/OCSE-FinalReport-Stuart-Khan-Final-28-May-2014.pdf (accessed 18.04.18).

Khatib, Z., Verbeek, P., 2002. Water to value: Produced water management for sustainable field development of mature and green fields, in: SPE International Conference on Health, Safety and Environment in Oil and Gas Exploration and Production. Society of Petroleum 
Engineers, Kuala Lumpur, p. 4. doi:10.2118/73853-MS

Kuraimid, Z.K., 2013. Treatment of produced water in north Rumela oil field for re-injection application, in: SPE Kuwait Oil and Gas Show and Conference. Society of Petroleum Engineers, Kuwait City, p. 12. doi:10.2118/167670-MS

Kurz, B.A., Stepan, D.J., Glazewski, K.A., Stevens, B.G., Doll, T.E., Kovacevich, J.T., Wocken, C.A., 2016. Bakken water management practices and potential outlook. Grand Forks. Available at: http://www.undeerc.org/bakken/pdfs/Bakken_Water_Management_Practices_and_Potential _Outlook.pdf (accessed 18.04.18).

Maas, E. V., Grattan, S.R., 1999. Crop yields as affected by salinity, in: van Schilfgaarde, J., Skaggs, R.. (Eds.), Agricultural Drainage. American Society of Agronomy, pp. 55-108. doi:10.2134/agronmonogr38.c3

Maassen, S., 2016. Bibliometric analysis of research on wastewater irrigation during 1991-2014. Irrig. Drain. 65, 644-653.

Mace, J.E., Amrhein, C., Oster, J.D., 1999. Comparison of gypsum and sulfuric acid for sodic soil reclamation. Arid Soil Res. Rehabil. 13, 171-188.

Maguire-Boyle, S.J., Barron, A.R., 2014. Organic compounds in produced waters from shale gas wells. Environ. Sci. Process. Impacts 16, 2237-2248.

Martel-Valles, F., Benavides-Mendoza, A., Mendoza-Villarreal, R., Zermeño-González, A., Juárez-Maldonado, A., 2014. Agronomic use of produced water in tomato plants under greenhouse conditions. Rev. Int. Contam. Ambient. 30, 365-377.

Martel-Valles, J.F., Foroughbakchk-Pournavab, R., Benavides-Mendoza, A., 2016. Produced waters of the oil industry as an alternative water source for food production. Rev. Int. 
Contam. Ambient. 32, 463-475.

Maton, L., Psarras, G., Kasapakis, G., Ravn Lorenzen, J., Andersen, M., Boesen, M., Nøhr Bak, S., Chartzoulakis, K., Marcus Pedersen, S., Kloppmann, W., 2010. Assessing the net benefits of using wastewater treated with a membrane bioreactor for irrigating vegetables in Crete. Agric. Water Manag. 98, 458-464.

McCormack, P., Jones, P., Hetheridge, M.., Rowland, S.., 2001. Analysis of oilfield produced waters and production chemicals by electrospray ionisation multi-stage mass spectrometry (ESI-MSn). Water Res. 35, 3567-3578.

Millenium Ecosystem Assessment, 2005. Ecosystems and Human Well-Being: Desertification Synthesis. World Resources Institute, Washington DC. Available at: http://collections.unu.edu/view/UNU:2636 (accessed 18.04.18).

Miller, J., 2010. California drought is no problem for Kern County oil producers [WWW Document]. URL http://www.circleofblue.org/2010/world/california-drought-is-noproblem-for-kern-county-oil-producers/ (accessed 3.8.17).

Mullins, G.L., Hajek, B.F., 1998. Effects of coalbed methane-produced water on sorghumsudangrass growth and soil chemical properties. Commun. Soil Sci. Plant Anal. 29, 23652381.

Myers, J.E., 2014. Chevron San Ardo Facility Unit (SAFU) Beneficial Produced Water Reuse for Irrigation, in: SPE International Conference on Health, Safety and Environment. Society of Petroleum Engineers, Long Beach, pp. 1-11.

Neff, J., 2002. Chapter 1: Produced water, in: Neff, J. (Ed.), Bioaccumulation in Marine Organisms: Effect of Contaminants from Oil Well Produced Water. Elsevier, Amsterdam, p. 468. doi:10.1016/S0146-6380(02)00213-9 
Neff, J., Lee, K., DeBlois, E.M., 2011. Produced Water: Environmental Risks and Advances in Mitigation Technologies, 6th ed. Springer, New York. doi:10.1007/978-1-4614-0046-2

NSW Government, 2013. Water and Coal Seam Gas Fact Sheet 4: Managing coal seam gas produced water. New South Wales Government, Office of Water. Parramatta. Available at: http://www.water.nsw.gov.au/_data/assets/pdf_file/0010/548713/groundwater_coal_seam_ gas_managing_produced_water.pdf(accessed 18.04.18).

NSW Government, 2011. Water pollution and the freshwater crisis. New South Wales (NSW)

$\begin{array}{lll}\text { Government } & \text { [WWW } & \text { Document }] .\end{array}$ http://www.environment.nsw.gov.au/stormwater/HSIEteachguide/WaterPoln.htm (accessed 3.8.17).

Pedrero, F., Kalavrouziotis, I., Alarcón, J.J., Koukoulakis, P., Asano, T., 2010. Use of treated municipal wastewater in irrigated agriculture: Review of some practices in Spain and Greece. Agric. Water Manag. 97, 1233-1241.

Pedrick, C., 2012. Strategies for Combating Climate Change in Drylands Agriculture, in: International Conference on Food Security in Drylands. ICARDA, Doha, p. 27. Available at: $\quad$ http://ccafs.cgiar.org/publications/strategies-combating-climate-change-drylandsagriculture-synthesis-dialogues-and (accessed 18.04.18).

Pichtel, J., 2016. Oil and gas production wastewater: Soil contamination and pollution prevention. Appl. Environ. Soil Sci. 2016, 24.

Qadir, M., Drechsel, P., 2016. Contaminant Management in Water Reuse Systems, in: Eslamian, S. (Ed.), Urban Water Reuse Handbook. CRC Press, Boca Raton, pp. 525-532.

Qadir, M., Sato, T., 2015. Water Reuse in Arid Zones, in: Eslamian, S. (Ed.), Urban Water Reuse Handbook. CRC Press, Boca Raton, pp. 867-874. 
Qadir, M., Sharma, B.R., Bruggeman, A., Choukr-Allah, R., Karajeh, F., 2007. Nonconventional water resources and opportunities for water augmentation to achieve food security in water scarce countries. Agric. Water Manag. 87, 2-22.

Rambeau, O., Morales de Lafond, R., Baldoni, P., Gosselin, J.P., Baccou, J.C., 2004. Low salt petroleum produced water reuse: A farming alternative outside the food chain. Water Sci. Technol. 50, 139-147.

Rattan, R.K., Datta, S.P., Chhonkar, P.K., Suribabu, K., Singh, A.K., 2005. Long-term impact of irrigation with sewage effluents on heavy metal content in soils, crops and groundwater: A case study. Agric. Ecosyst. Environ. 109, 310-322.

Reid, V., 2014. Drylands: some of the most biodiverse habitats in the world. Biodiversity 15, 6566.

Rhoades, J.D., Kandiah, A., Mashali, A.., 1992. The use of saline waters for crop production (No. 48), FAO Irrigation and Drainage Paper. Rome.

Rice, C., Nuccio, V., 2000. Water produced with coal-bed methane. U.S Geol. Surv. Available at: http://pubs.usgs.gov/fs/fs-0156-00/fs-0156-00.pdf (accessed 18.04.18).

Robles, H., 2016. Irrigation Water Quality Evaluation Cawelo Water District Bakersfield, California. Available

at: http://www.waterboards.ca.gov/rwqcb5/water_issues/oil_fields/food_safety/data/studies/ca welo_irrstudy.pdf (accessed 18.04.18).

Safriel, U., Adeel, Z., Niemeijer, D., Puigdefabregas, J., White, R., Lal, R., Winslow, M., Ziedler, J., Prince, S., Archer, E., King, C., Shapiro, B., Wessels, K., Nielsen, T., Portnov, B., Reshef, I., Thonell, J., Lachman, E., McNab, D., 2006. Chapter 22: Dryland Systems, in: El-Kassas, M., Ezcurra, E. (Eds.), Ecosystems and Human Well-Being: Current State and 
Trends, Volume 1. Island Press, Washington DC, pp. 625-656.

Scanlon, B.R., Reedy, R.C., Nicot, J.-P., 2014. Comparison of water use for hydraulic fracturing for unconventional oil and gas versus conventional oil. Environ. Sci. Technol. 48, 1238612393.

Shah, Y.T., 2014. Chapter 2: Role of Water in Recovery and Production of Raw Fuels, in: Water for Energy and Fuel Production. CRC Press, Boca Raton, pp. 17-32.

Sharr, A., 2014. Water management trends and the Eagle Ford. Presentation at the EFCREO Shale Oil and Gas Development Workshop: Management of Water Resources, Air $\begin{array}{lll}\text { Resources and } & \text { Oilfield }\end{array}$ http://www.tamuk.edu/eagleford/pdf/Baker_Hughes_April Sharr.pdf (accessed 18.04.18).

Sluijterman, A.C., Al-Lawati, Y., Al-Asmi, S., Verbeek, P.H.J., Schaapveld, M.A.S., Cramwinckel, J., 2004. Opportunities for re-use of produced water around desert oil fields, in: Abu Dhabi International Conference and Exhibition. SPE, Abu Dhabi, pp. 1-7. doi:10.2118/88667-MS

Sorkhabi, R., 2010. The King of Giant Fields. Geoexpro 7, 24-31. Available at: http://www.geoexpro.com/articles/2010/04/the-king-of-giant-fields (accessed 18.04.18).

Sorrell, S., Speirs, J., Bentley, R., Miller, R., Thompson, E., 2011. Shaping the global oil peak: A review of the evidence on field sizes, reserve growth, decline rates and depletion rates. Energy 37, 709-724.

SPE, 2011. Challenges in reusing produced water: SPE White Paper. Soc. Pet. Eng. 1-6. Available at: http://www.spe.org/industry/challenges-in-reusing-produced-water.php (accessed 18.04.18).

Stanic, J., 2014. Unconventional oil and gas production drives trends in water management and 
treatment. Glob. Water Intell. 10-15. Available at: http://spe.org/en/print-article/?art=269 (accessed 18.04.18).

Stefanakis, A., 2016. Chapter 19: Ecological impact of water reuse, in: Eslamian, S. (Ed.), Handbook of Urban Water Reuse. CRC Press, Boca Raton, pp. 219-227.

Stephenson, M.T., 1992. Part 1: A survey of produced water studies, in: Ray, J.P., Engelhardt, F.R. (Eds.), Produced Water: Technological Environmental Issues and Solutions. Springer, Boston, pp. 1-13. doi:10.1007/978-1-4615-2902-6

Sullivan Graham, E.J., Jakle, A.C., Martin, F.D., 2015. Reuse of oil and gas produced water in south-eastern New Mexico: Resource assessment, treatment processes, and policy. Water Int. 40, 809-823.

Sumner, M.E., 1993. Sodic soils: New perspectives. Aust. J. Soil Res. 31, 683-750.

Szép, A., Kohlheb, R., 2010. Water treatment technology for produced water. Water Sci. Technol. 62, 2372-2380. doi:10.2166/wst.2010.524

Tal, A., 2016. Rethinking the sustainability of Israel's irrigation practices in the drylands. Water Res. 90, 387-394.

Terrel, H., 2015. Oil in water: Good to the last microdrop. World Oil 23. Available at: http://www.nov.com/WorkArea/DownloadAsset.aspx?id=13137 (accessed 18.04.18).

Toze, S., 2006. Reuse of effluent water: Benefits and risks. Agric. Water Manag. 80, 147-159.

Transparency Market Research, 2016. Produced water treatment systems market: Global industry analysis, size, share, growth, trends and forecast 2012-2020. Albany.

UN, 2012. Managing Water under Uncertainty and Risk. The Unided Nations (UN) World Water Development Report 4, Volume 1. Paris. Available at: http://www.unesco.org/new/fileadmin/MULTIMEDIA/HQ/SC/pdf/WWDR4 Volume 1- 
Managing Water under Uncertainty and Risk.pdf (accessed 18.04.18).

UN, 2010. 2010-2020: United Nations (UN) decade for deserts and the fight against desertification [WWW Document]. URL http://www.un.org/en/events/desertification_decade/whynow.shtml (accessed 3.8.17).

US Department of Agriculture, 2015. California Drought: Crop Sectors [WWW Document]. URL http://www.ers.usda.gov/topics/in-the-news/california-drought-farm-and-foodimpacts/california-drought-crop-sectors.aspx (accessed 3.8.17).

US Department of Commerce, 2015. Bureau of Economic Analysis [WWW Document]. URL http://www.bea.gov/ (accessed 3.8.17).

US EPA, 1995. United States Environmental Protection Agency (US EPA), Code of Federal Regulations, Title 40-Protection of Environment, Chapter I, Subchapter N, Part 435-Oil and Gas Extraction Point Source Category, Subpart E-Agricultural and Wildlife Water Use Subcate [WWW Document]. Electron. Code Fed. Regul. URL http://www.ecfr.gov (accessed 4.18.18).

USGS, 2016. U.S. Geological Survey National Produced Waters Geochemical Database v2.2 [WWW Document].

URL http://energy.usgs.gov/EnvironmentalAspects/EnvironmentalAspectsofEnergyProductionan dUse/ProducedWaters.aspx (accessed 6.19.17).

Van Voast, W.A., 2003. Geochemical signature of formation waters associated with coalbed methane. Am. Assoc. Pet. Geol. Bull. 87, 667-676.

Vance, G.F., King, L.A., Ganjegunte, G.K., 2004. Soil and plant responses from land application of saline-sodic waters: Implications of management. J. Environ. Qual. 37, S139-48.

Vaz, L., Di Falco, G., 2011. Advanced produced-water treatment \& reuse for oilfields. Water 
Today

$36-46$.

Available

at:

http://pdfs.semanticscholar.org/1c77/4e301c94e476fbedd86a8a2eb36b5a4aa351.pdf (accessed 18.04.18).

Veil, J., 2011. Produced Water Management Options and Technologies, in: Lee, K., Neff, J. (Eds.), Produced Water: Environmental Risks and Advances in Mitigation Technologies. Springer, New York, pp. 537-571. doi:10.1007/978-1-4614-0046-2_29

Veil, J., Puder, M.G., Elcock, D., Redweik, R.J., 2004. A white paper describing produced water from production of crude oil, natural gas, and coal bed methane. Available at: http://109.4iranian.com/uploads/prodwaterpaper_1270.pdf (accessed 18.04.18).

Waldron, J., 2005. Southwest Hydrology. SAHRA, NSF Sci. Technol. Cent. 26-27. Available at: http://www.swhydro.arizona.edu/archive/V4_N6/feature5.pdf (accessed 18.04.18).

Wang, W., Li, X., Chen, Y., Zhang, S., Jiang, Y., 2001. The technology of microbial treating drained water of oil field, in: SPE Asia Pacific Improved Oil Recovery Conference. Society of Petroleum Engineers, Kuala Lumpur, p. 4. doi:10.2118/72192-MS

Water Online, 2014. Testing the waters for offshore treatment [WWW Document]. URL http://www.wateronline.com/doc/testing-the-waters-for-offshore-treatment-0001 (accessed 3.8.16).

Waterfind, 2016. California Water Board to investigate use of oilfield wastewater to irrigate crops [WWW Document]. URL http://www.waterfindusa.com/news-posts/california-waterboard-to-investigate-use-of-oilfield-wastewater-to-irrigate-crops/ (accessed 3.8.17).

Williams, E.., Simmons, J.., 2013. Chapter 2: Water in fossil fuel and uranium extraction, in: Williams, E.. (Ed.), Water in the Energy Industry: An Introduction. pp. 17-44. Available at: http://www.bp.com/content/dam/bp/pdf/sustainability/group-reports/BP-ESC-water- 
handbook.pdf (accessed 18.04.18).

Wolf, D.C., Brye, K.R., Gbur, E.E., 2015. Using soil amendments to increase Bermuda grass growth in soil contaminated with hydraulic fracturing drilling fluid. Soil Sediment Contam. An Int. J. 24, 846-864.

$\begin{array}{lllll}\text { World Bank } & \text { [WWW } & \text { Document } & 2016 . & \text { URL }\end{array}$ http://data.worldbank.org/indicator/SP.POP.TOTL?locations=ZQ (accessed 3.8.17).

Xu, P., Drewes, J.E., Heil, D., 2008. Beneficial use of co-produced water through membrane treatment: Technical-economic assessment. Desalination 225, 139-155. 